\title{
PRODUÇÃO DA PAISAGEM URBANA CONTEMPORÂNEA BRASILEIRA NO FINAL DO SÉCULO 20
}

Silvio Soares Macedo

Arquiteto, professor titular de Paisagismo do Departamento de Projeto da Faculdade de Arquitetura e Urbanismo da Universidade de São Paulo editor da Revista Paisagem e Ambiente - Ensaios da FAUUSP.

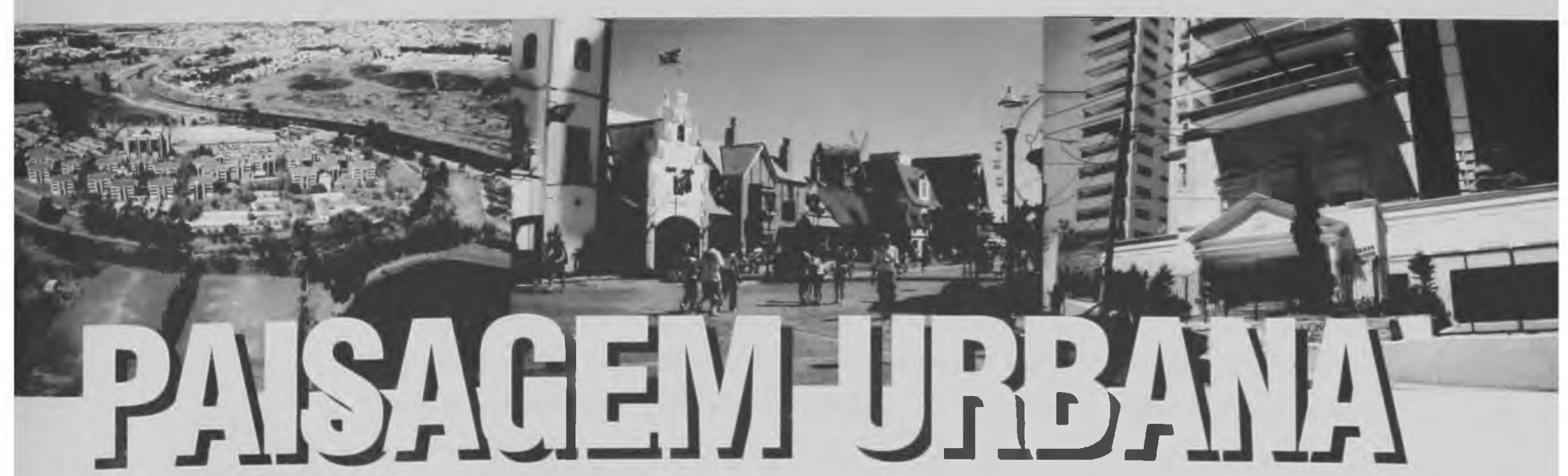




\section{RESUMO}

Este texto objetiva traçar um panorama geral da constituição da paisagem brasileira urbana ao final do século 20. São apontadas as formas de organização da paisagem urbana, que refletem as contradições da sociedade neste período, dando-se ênfase a questões como privacidade, segregação e aumento da demanda por espaços livres. A última parte é dedicada a uma avaliação dos rebatimentos dessas demandas e da liberdade cultural vigente sobre os novos projetos paisagísticos.

\section{ABSTRACT}

This paper focuse an overview about the Brazilian Contemporary Urban Landscape at the end of the $20^{\text {th }}$ century, their new kinds of patterns of organization, the privatization of the criation of the opens spaces, the segregation and the new necessities of open public spaces. The last part is dedicated to an evolution of the new design patterns over the contemporary landscape projects. 


\section{PRODUÇÃO DA PAISAGEM URBANA CONTEMPORÂNEA BRASILEIRA NO FINAL DO SÉCULO 20}

Paisagem - um termo direto que representa o espaço construído pelo acúmulo das ações das gerações sobre a superfície do planeta, que é constantemente transformada, tanto pelo crescimento vegetativo dos seres vivos como pelas grandes e pequenas mudanças geológicas, pelo clima, pelo passar das estações dos anos e pela ação da sociedade.

A paisagem é, então, um produto destas transformações e é claramente codificada e percebida pelas sociedades como imagens, duradouras ou fugidias, que passam e são percorridas pelo ser humano no seu cotidiano, que a utiliza à larga, como lugar de vida e trabalho.

O final do século 20 marca uma nova referência na constituição da paisagem brasileira, que assume novas configurações morfológicas, na medida em que exprime e representam as intenções sociais e contemporâneas da sociedade nacional, então em um franco processo de transformação e liberação econômica.

O aumento das fronteiras agrícolas e minerais, a acessibilidade cada vez maior a todos os pontos do território nacional, tanto por via terrestre quanto por via aérea, a navegabilização dos rios e especialmente o crescimento urbano acelerado, que indicam nos anos 80 e 90 uma população predominantemente urbanizada, explicam e justificam as configurações então existentes.

Estas configurações expressam as grandes desigualdades sociais do país, a forma racional ou predatória dos novos assentamentos e plantios, a grande dificuldade de controle efetivo dos recursos paisagísticos e ambientais, o sucesso estrondoso da implantação de áreas segregadas para classes de maior poder aquisitivo, que buscam suprir, a seu modo, as deficiências de controle social do poder público sobre o seu dia-a-dia, e a construção de extensas áreas urbanas informais, nas quais a pobreza e a falta de acesso à propriedade da terra explicam a sua existência.

A leitura simples desses fatos se apresenta ao usuário, comum e muitas vezes atônito, como uma imagem caótica, iá que ele pouco ou nada entende da totalidade das suas lógicas de formação, existindo de fato na sociedade um baixo teor crítico às estruturas paisagísticas que se configuram. 
modersing

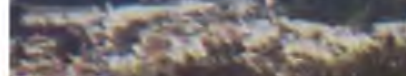

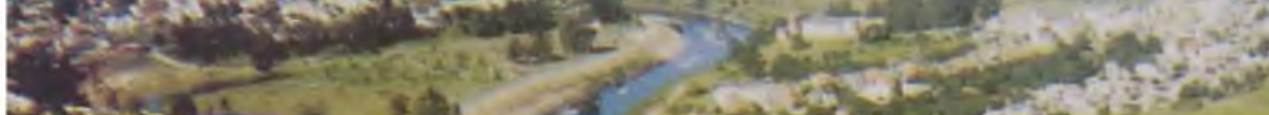

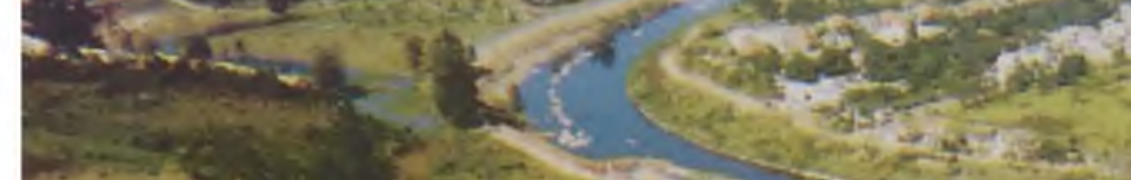

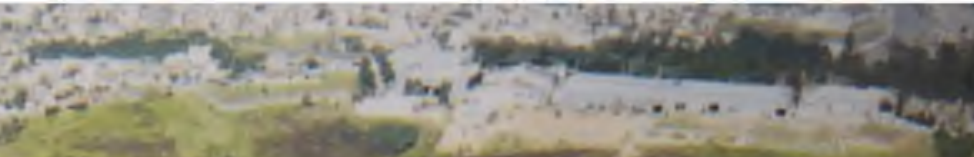

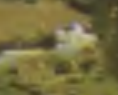

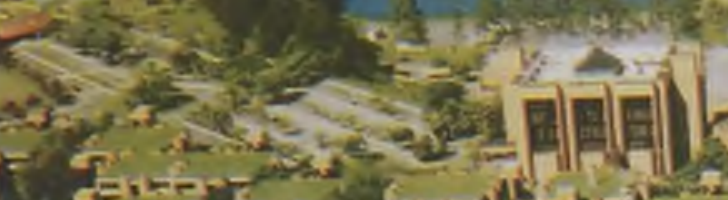

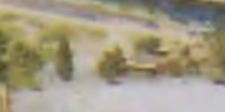

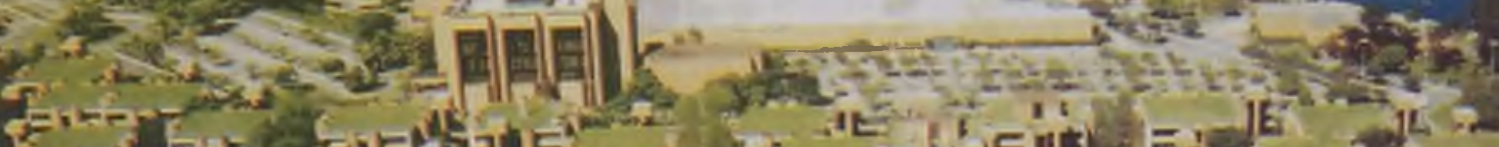

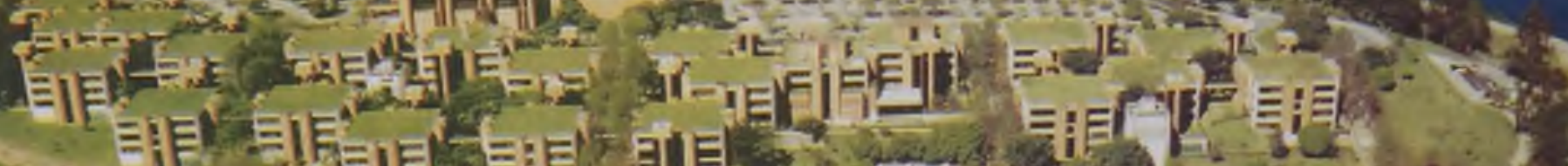
EIE EIE

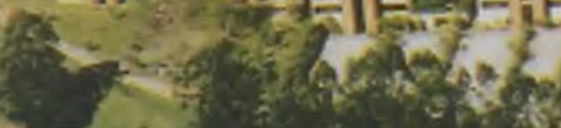

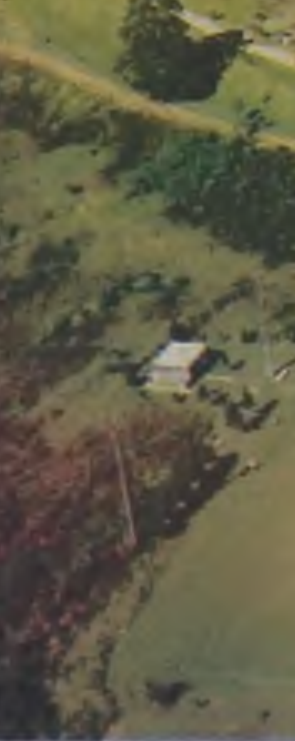

Figura 1 - A construçāo de novas paisagens sobre áreas já intensamente transformadas - Alphaville - SP Fonte: Foto do autor (1998)

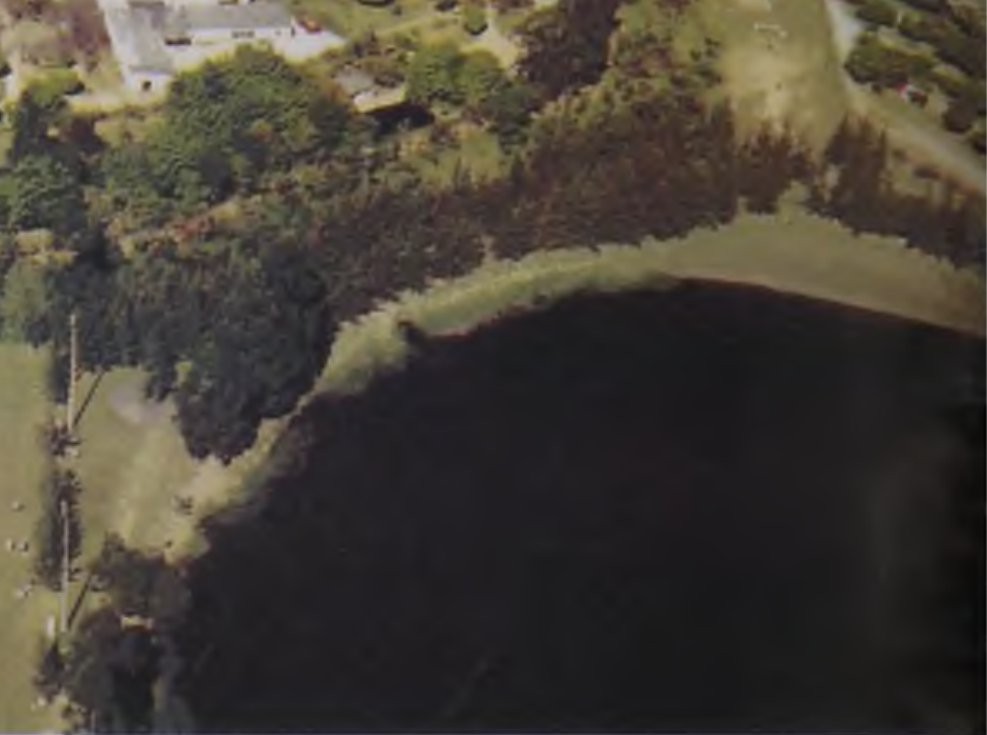

Figura 7A - Bairro Jardim - Barra da Tijuca

Fonte: Foto do autor (fev. 1999)

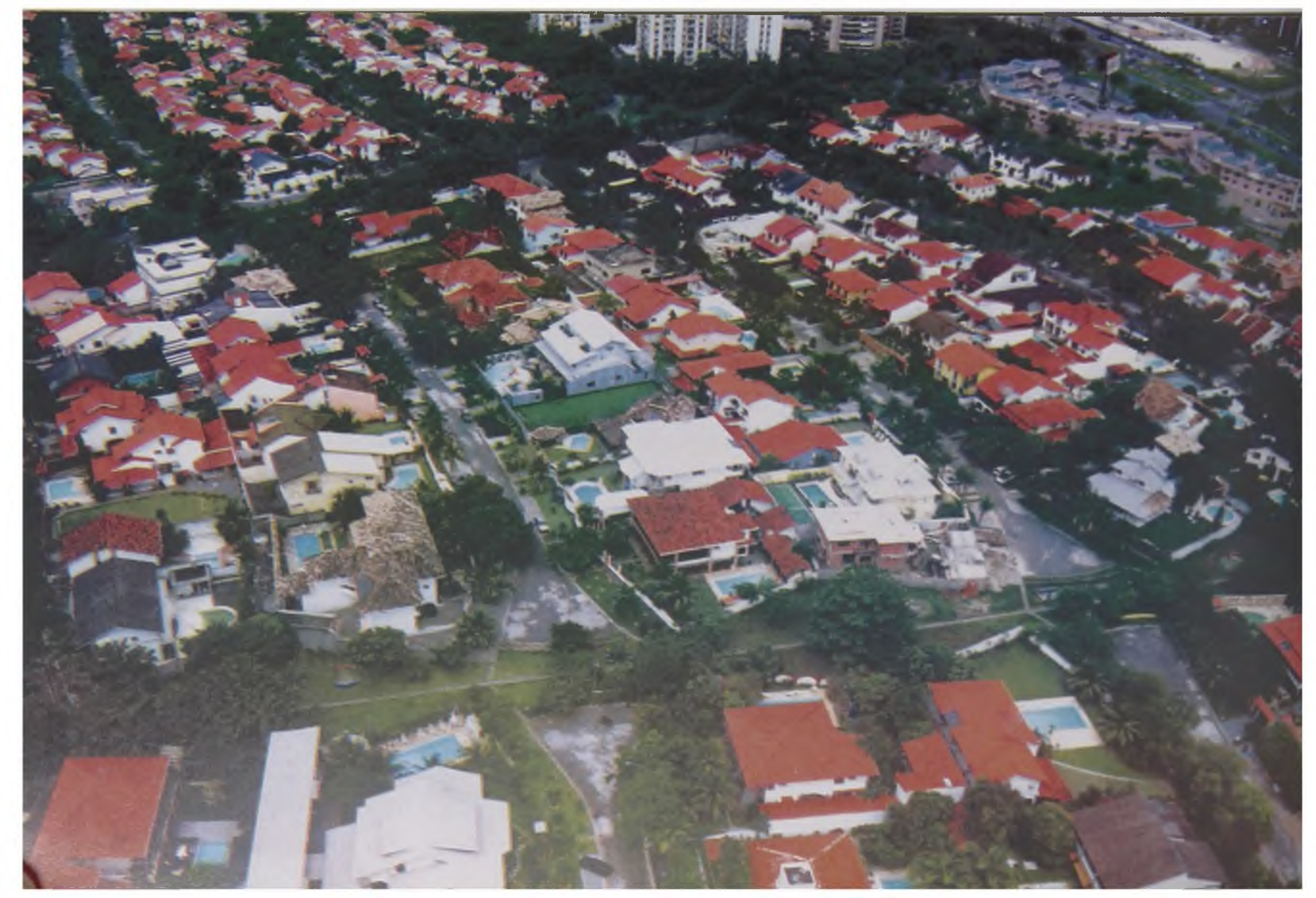




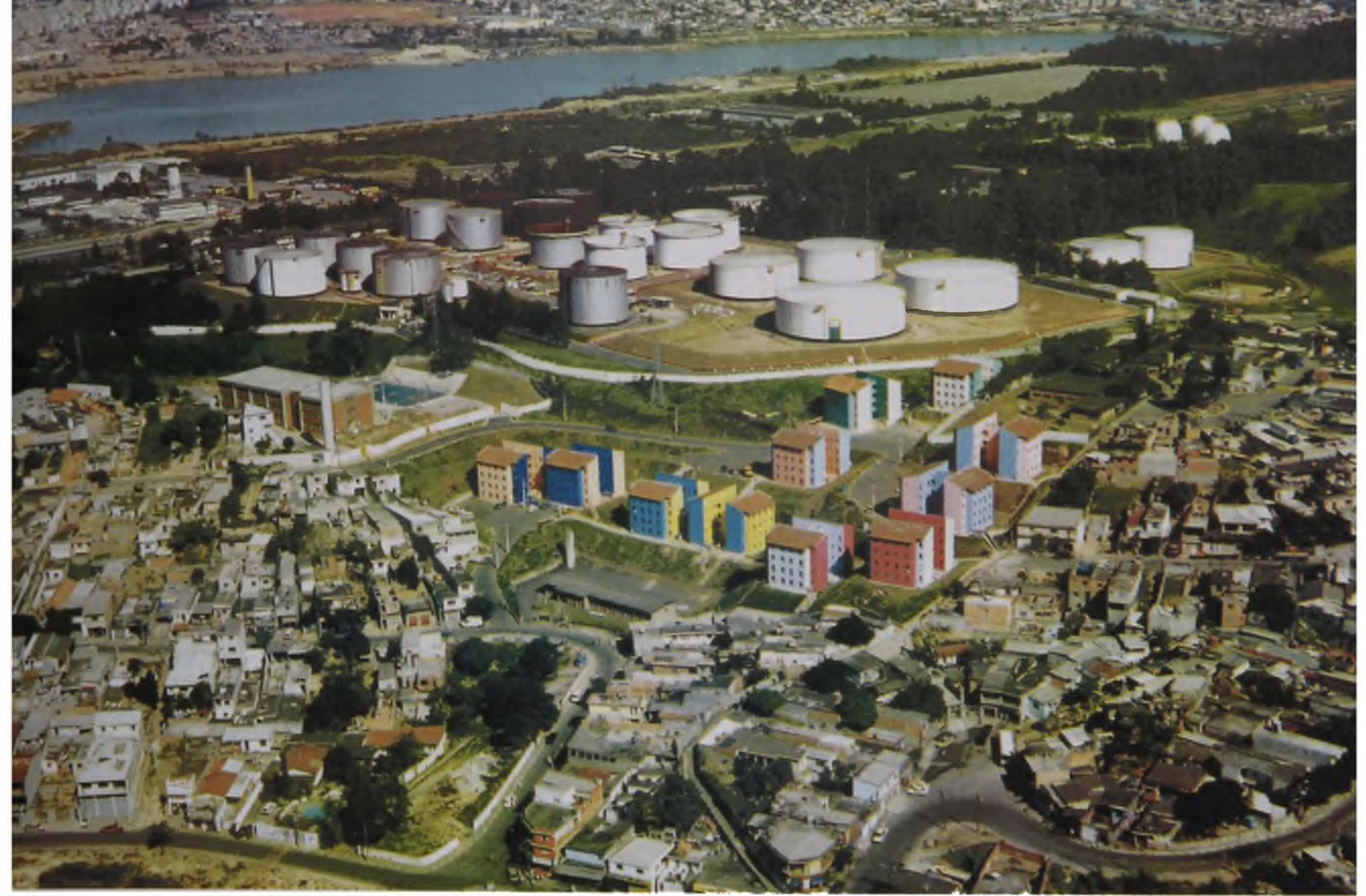

Figura 2 - Casario e indústrias - Barueri/Osasco/Alphaville

Fonte: Foto do autor (1998)

\section{Paisagem Urbana}

Os sonhos e os ideais de consumo vigentes no século 20 direcionaram no país, durante todo o século, a tomada de alguns parâmetros comuns de qualidade para uma paisagem urbana. O local ideal para se habitar e trabalhar, dentro do urbano, deve ser preferencialmente acessível ao automóvel, cercado por verde, constituído de construções edificadas dentro dos ditames da arquitetura da moda, seja ela o chalé normando, o prédio moderno ou a torre "néo-qualquer-coisa", com um arruamento impecável, situadas em um local alto e aprazível, ou à beira-mar, ou até mesmo em lugares totalmente desprovidos de qualquer interesse paisagístico explicitamente aceito pela sociedade, mas envolvidos por áreas tratadas urbanisticamente de um modo similar, isoladas e cercadas por muros altos (característica dos condomínios dos anos 90).

Estes ideais perpassam todas as classes sociais e são difundidos à larga pela "mídia" e pela televisão, em especial, que em suas novelas populares apresentam no cotidiano da família brasileira ícones e cenários paisagísticos, que pouco a pouco são assimilados como padrões de qualidade e como objetos de consumo por quase a totalidade da população nacional, e vendidos para os que podem pagar pelo mercado imobiliário, sempre lançador de novos produtos. 
São apresentados, como paisagens ideais, os condomínios verdejantes, as praias idílicas, a natureza intocada, enseadas e baías azuis singradas por iates e barcos esportivos, vilas românticas e parques bucólicos, por onde desfilam os personagens, heróis e vilões, dos folhetins virtuais.

A realidade mostra uma urbanização intensiva e extensiva, com o constante crescimento das áreas suburbanas das cidades de médio e grande porte e das áreas metropolitanas, e com a expansão da urbanização destinada ao turismo de segunda residência, que restrutura extensas áreas tanto no interior como na zona costeira para tal finalidade.

crescimento urbano se caracteriza pela suburbanização intensiva tanto de bairros ricos como populares e por um processo de verticalização de porte, fruto de uma indústria de construção e imobiliária em expansão, que transforma extensas áreas e, portanto, paisagens consolidadas em novas paisagens, alterando de um modo expressivo a hierarquia e a constituição de seus espaços públicos e privados.

processo de verticalização tradicionalmente se dá sobre áreas dotadas de infra-estrutura implantada e consolidadas, substituindo as construçōes existentes por outras tantas novas, especialmente em áreas ocupadas pela camada de maior poder aquisitivo, para as quais, em geral, são destinados os novos prédios de apartamentos. Somente nas últimas décadas do século, em algumas áreas novas, observa-se um processo de urbanização verticalizada, como é o caso da Barra da Tijuca, na cidade do Rio de Janeiro, do condomínio Riviera de São Lourenço, no litoral norte de São Paulo, ou em algumas áreas de Aracajú, São Luís do Maranhão e Salvador.

Figura 5 - Aracajú - Área nova verticalizada

Fonte: Foto Cesar E. de Assis (2000)

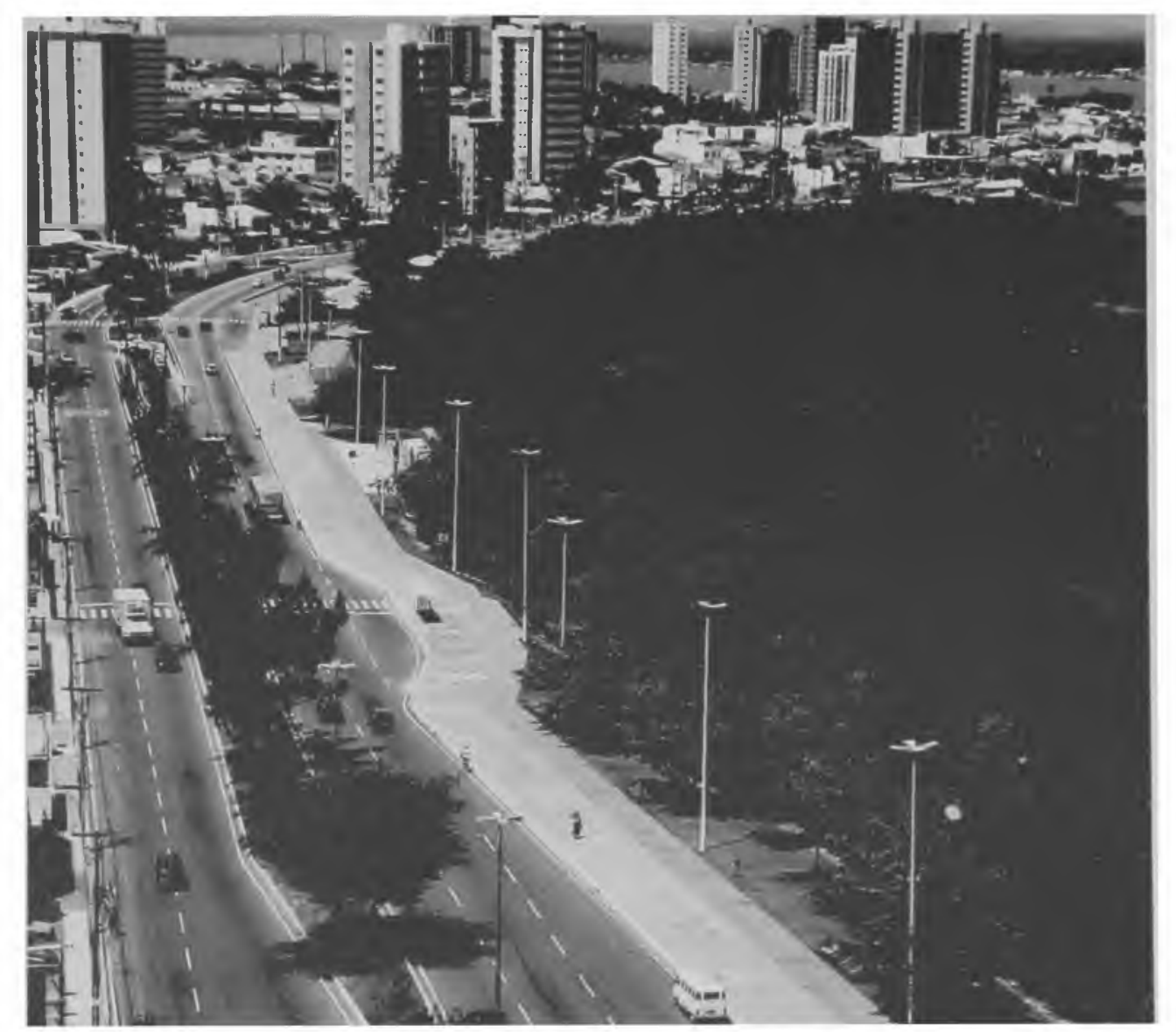


A construção intensiva de áreas de segunda residência é um processo típico da segunda metade do século 20, especialmente devido ao crescimento expressivo das classes médias, do acesso à propriedade do veículo automotor a uma parcela importante da população, da falta latente de investimentos do poder público em áreas de lazer nas cidades, em crônico processo de congestionamento, e do fato de a propriedade de um bem imóvel ser um fator de segurança financeira. Constitui-se, pois, o imóvel em uma reserva de capital de relativa liquidez, em uma economia constantemente instável, que garante do seu proprietário uma "segurança" para o futuro, seja pela renda de aluguéis, seja pela sua venda eventual.

Observa-se, então, em volta das grandes cidades, a construção de anéis de chácaras de veraneio, que transformam áreas, antes agrícolas, em amenas e bucólicas áreas de lazer, e a edificação de linhas extensas de loteamentos de casas de veraneio ao longo da grande maioria da costa. Pode-se constatar, ao findar do século, um intenso processo de loteamento das áreas fronteiriças ao mar, que se posicionam, de um modo que tende ao contínuo, do estado do Rio Grande do Sul ao Ceará. São milhares e milhares de residências e centenas de loteamentos dos mais diferentes padrōes, formas e tipos, que são construídos de um modo bastante destrutivo por (sobre) praias, dunas e áreas de restinga, causando a erradicação total da vegetação nativa e induzindo por muitas vezes a criação de paisagens totalmente padronizadas e diferenciadas da realidade até então existente.

Figura 6 - Subúrbio classe média paulistana - Pirituba - SP Fonte: Foto do autor (1998)

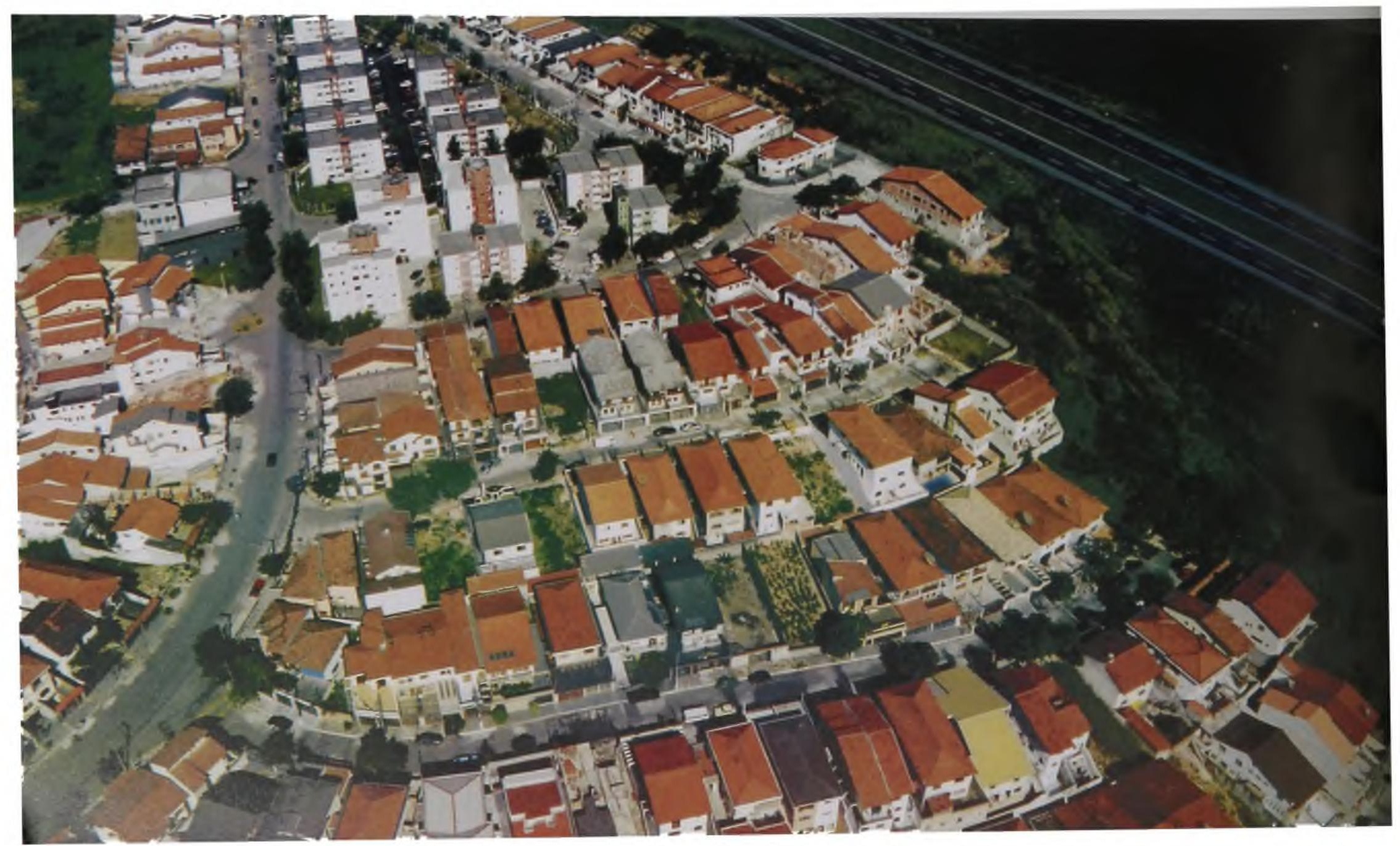


Reproduzem-se, no litoral, os ideais urbanísticos da cidade tradicional, da casa cercada de jardins, o objeto mais importante na configuração da grande maioria dos loteamentos costeiros, ou das fileiras de prédios de apartamentos, que são alinhados em alguns pontos de maior demanda turística, como no Balneário Camboriú (SC), Vila Velha (ES) ou Guarujá (SP) em frente de uma avenida praiana, que pode ou não possuir um calçadão ou jardins.

Figura 7 - Alphaville - condomínios verdejantes e segregados, Barveri - SP

Fonte: Foto do autor, 1998

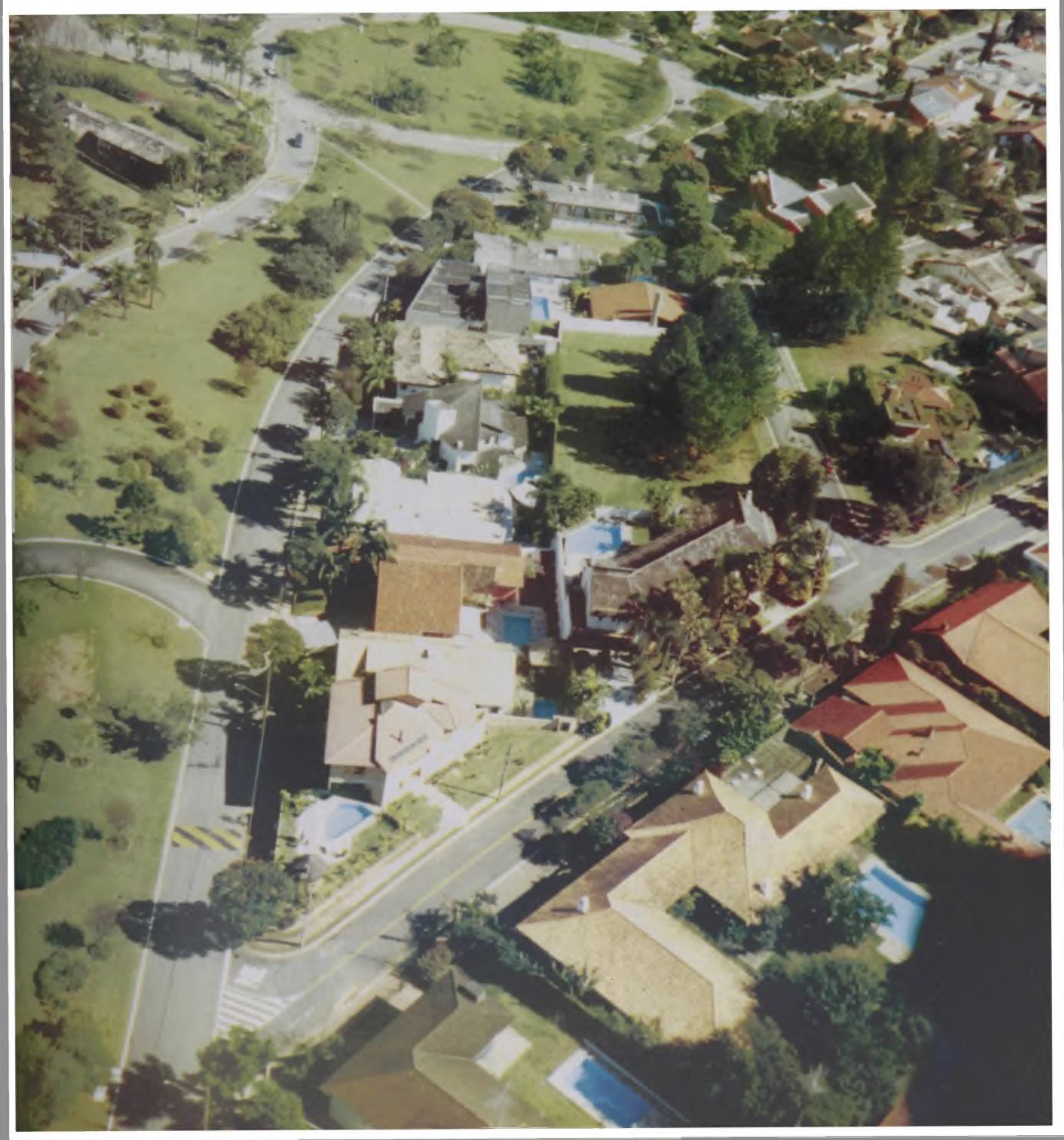



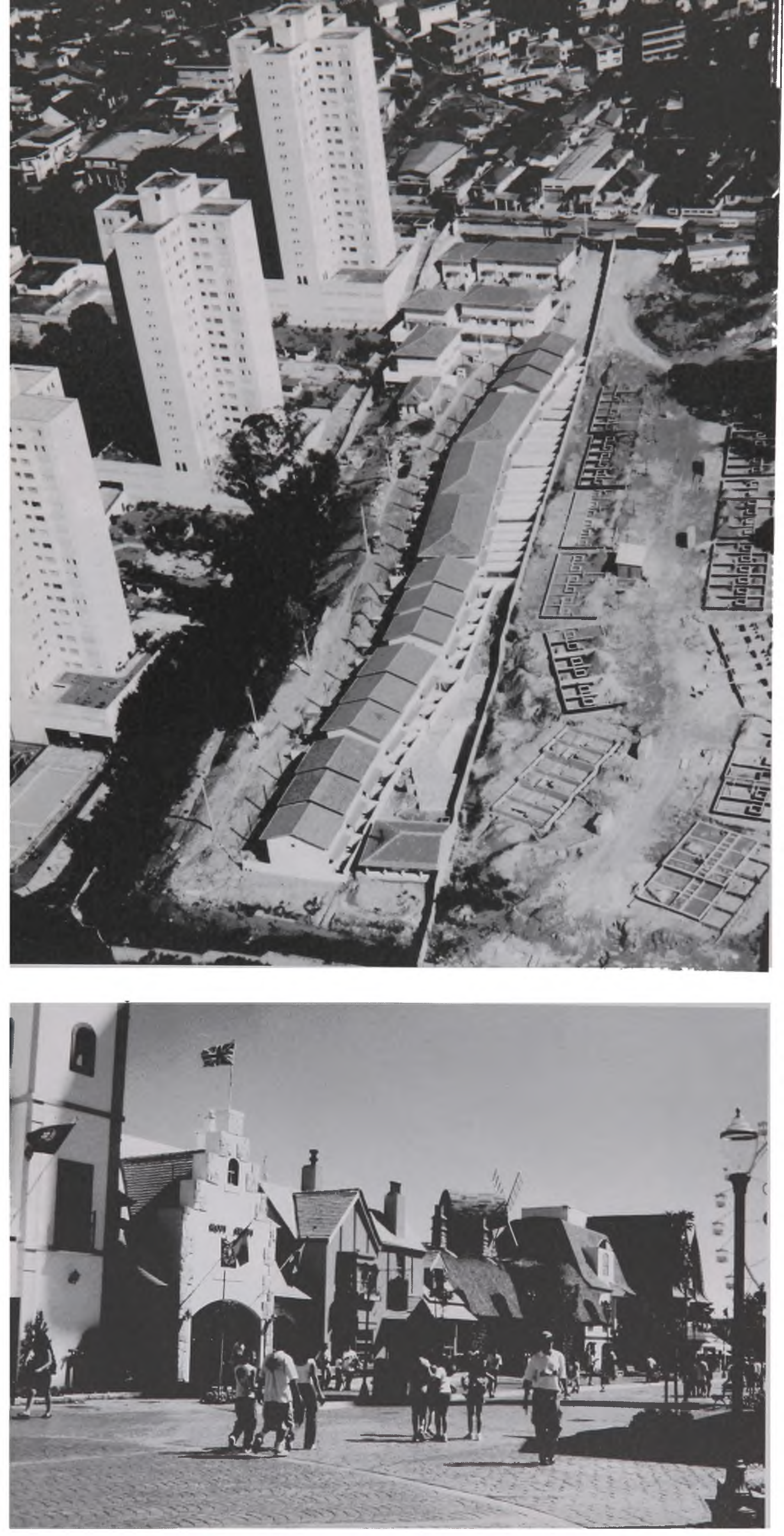

Figura $7 A$ - Vila em construção - SP

Fonte: Foto do autor (set. 1998)
Figura $7 A_{1}$ - Parque Temático Hopi Hari - SP Fonte: Foto do autor (2000) 


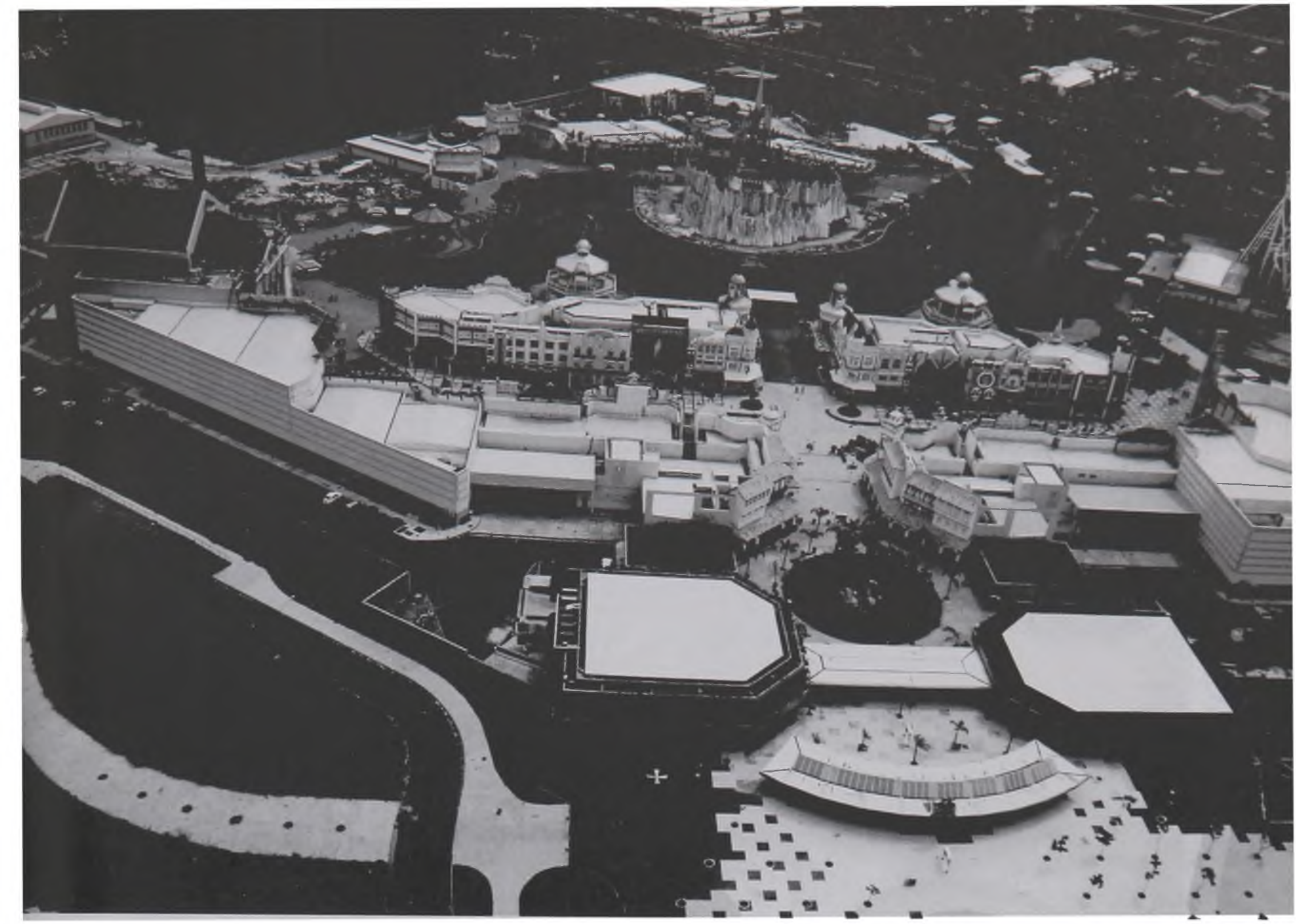

Figura 7 B - Parque Temático, Terra Encantada, Barra da Tijuca (vista aérea), RJ Fonte: Foto do autor (1999)

No interior, nas estâncias turísticas de montanha, outros ideais balizam a construção da paisagem, baseados na reprodução de cenas bucólicas das montanhas de países como a Suiça e a Áustria. Pinheirais e chalés e prédios de tetos inclinados e prontos para receber uma improvável neve são altamente valorizados, já que se associa, tradicionalmente, desde os tempos do segundo império, a idéia do veraneio ou da temporada invernal nas montanhas, a uma intenção hipotética de flanar por paisagens europeizadas. As cidades de Campos do Jordão (SP) e Petrópolis (RJ) apresentam nas suas paisagens trechos significativos, configurados dentro destes parâmetros.

\section{Figuras}

A paisagem das cidades é definida basicamente pela configuração e disposição de seus casarios, que por sua vez dependem exclusivamente das formas diferenciadas de parcelamento e propriedade vigentes. Edifícios diferenciados, palácios e monumentos, parques e praças são exceções no contexto da cidade comum e podem, quando existem, ser considerados como marco urbano. $\bigcirc$ conjunto urbano é de fato constituído por conjuntos contínuos de construções 
indiferenciadas no contexto geral, que abrigam atividades habitacionais, comércio e serviços, na maioria das vezes de configuração morfológica horizontal e, em alguns pontos, de configuração predominantemente vertical.

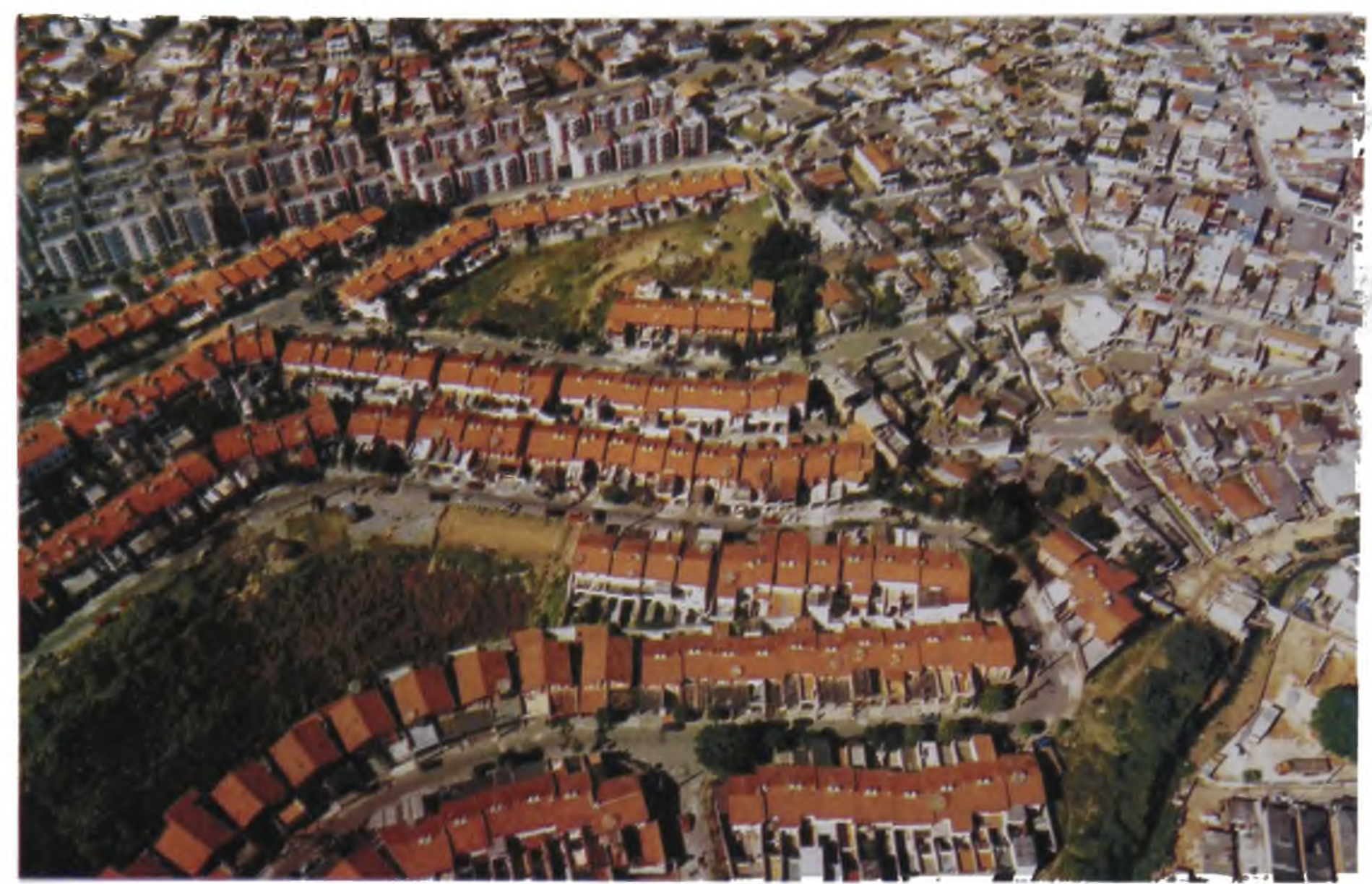

Figura 8 - Conjuntos e casarios - Subúrbio paulistano - Pirituba/SP Fonte: Foto do autor (1998)

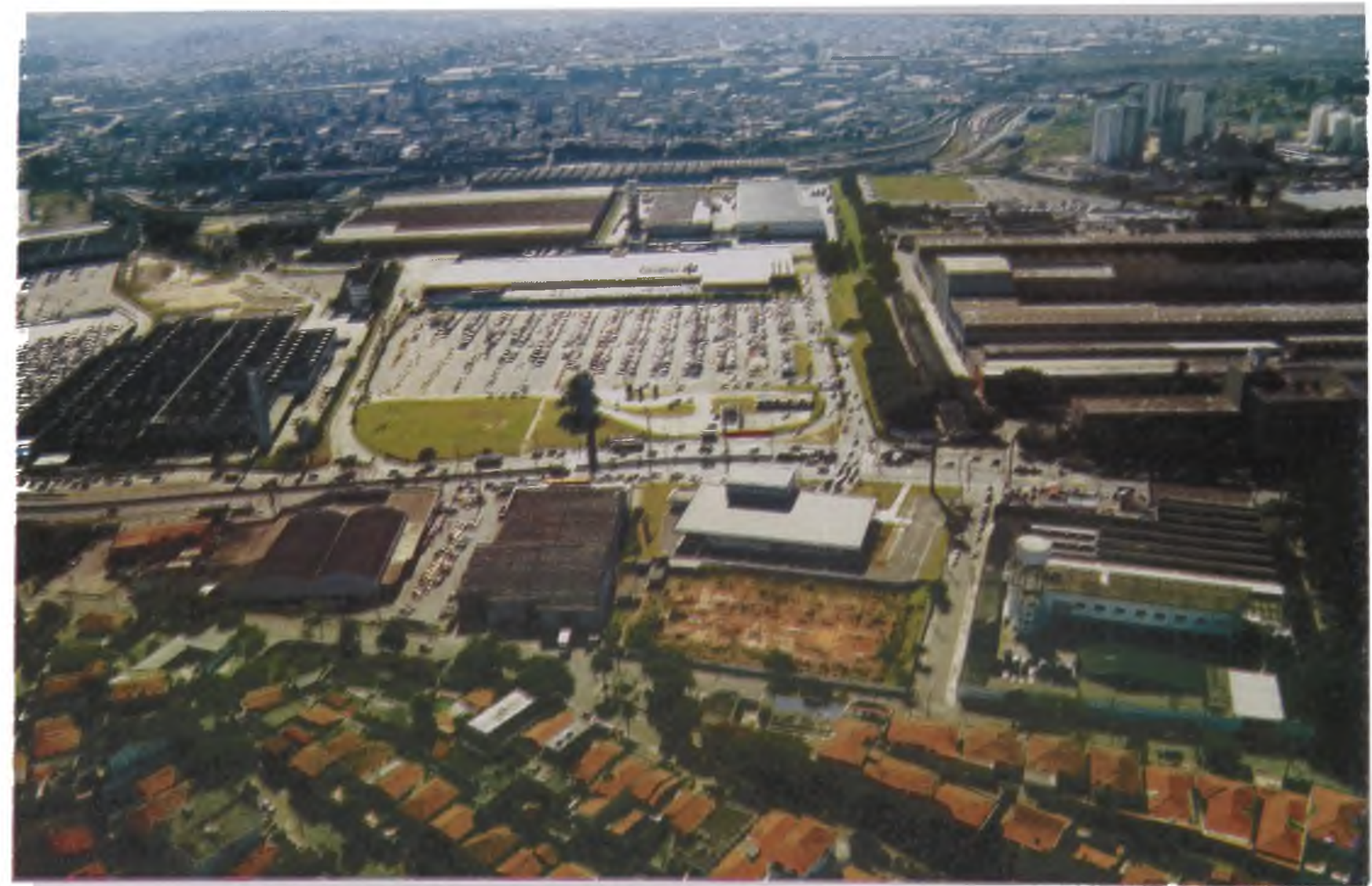

Figura 8 A - Centro de compras em Osasco/SP

Fonte: Foto do autor 


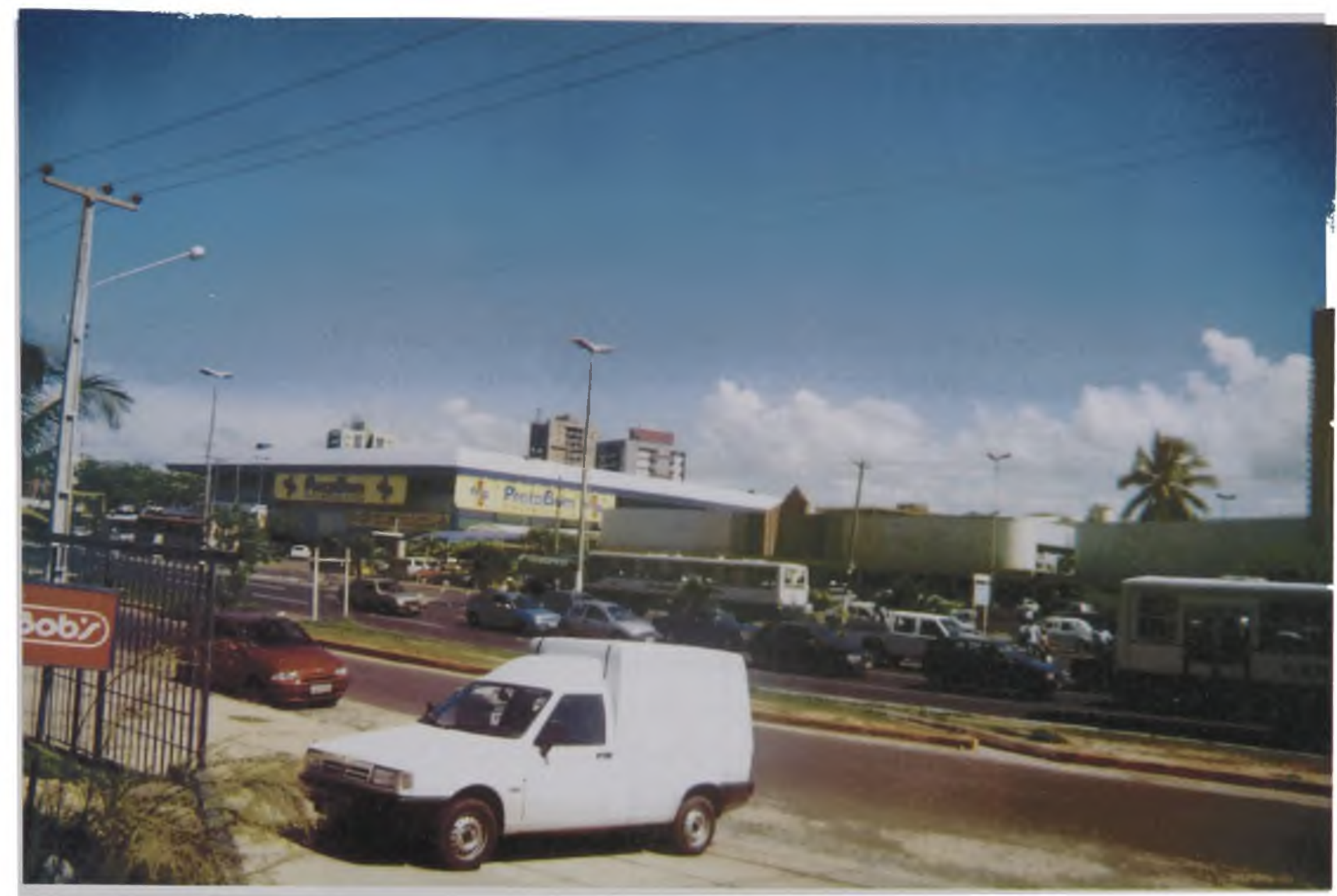

Figura 8 B - São Luís do Maranhão. Como em todas as grandes e médias cidades do Brasil, as avenidas e o comércio são estruturados para o automóvel

Fonte: Foto do autor

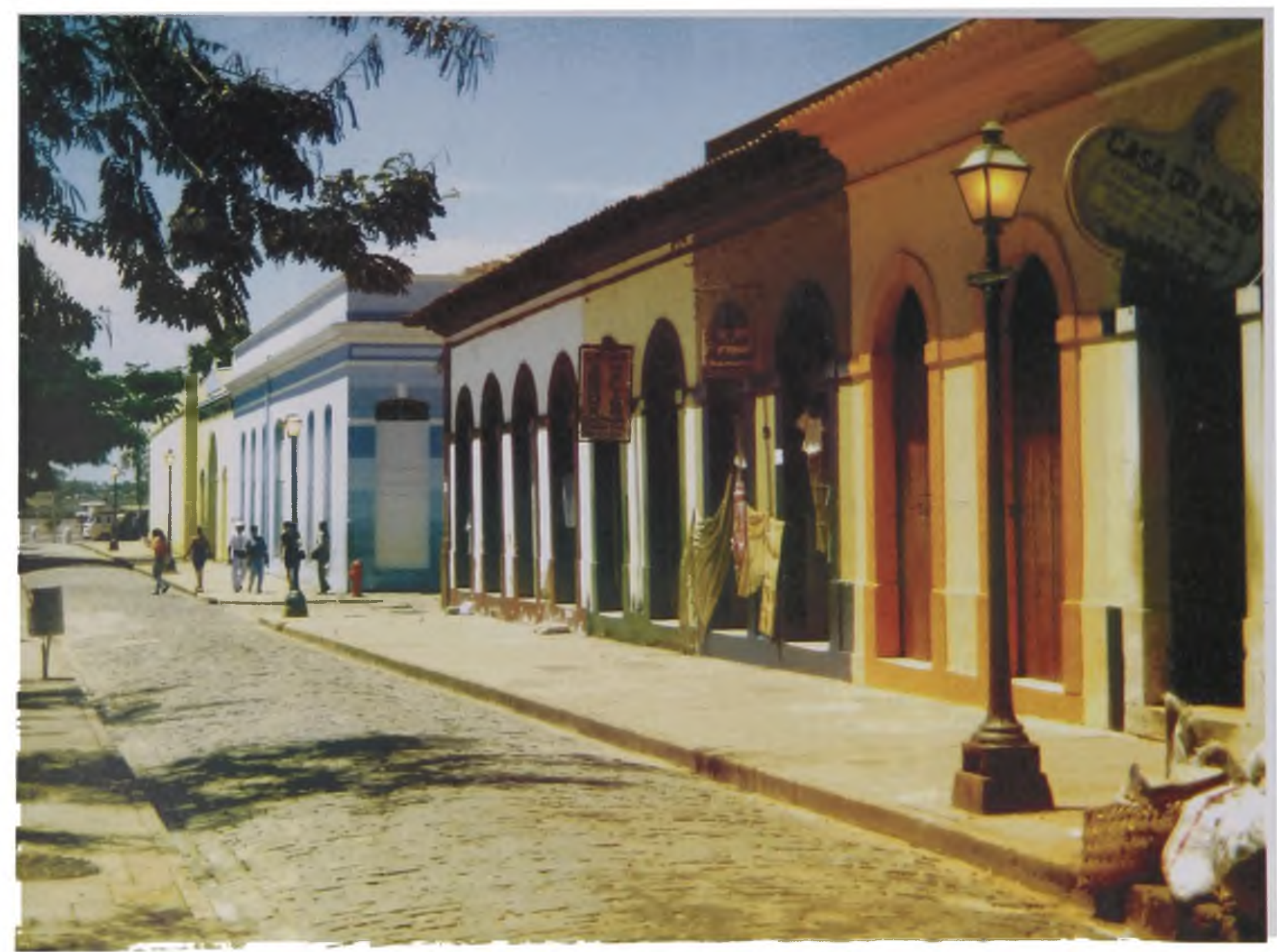

Figura 9 - São Luís do Maranhão - A revitalização cênica

Fonte: Francine Cramacho 
Este casario exprime na sua forma o resultado do seu processo de gestação, formal ou informal, em relação à sua vinculação a um controle público qualquer e contém os aspectos necessários à ocupação da camada social que o habita. Exprime de fato as contradições sociais vigentes no país, seja nos amplos setores urbanos constituídos de residências de alvenaria aparente, autoconstruídas em sua maioria pelos seus moradores, membros das camadas mais pobres e cujo aspecto genérico propicia uma imagem de improviso ou de provisório, seja naqueles outros destinados às camadas mais ricas, cuidadosamente arruados e dotados de generosos espaços livres, públicos e privados, ajardinados e arborizados, e dotados de edificações de boa qualidade construtiva e arquitetura vinculada às mais modernas correntes projetuais vigentes.

Neste segundo universo, constituem-se evidentes e acintosas formas de segregação, expressas nos novos condomínios amuralhados, que objetivam teoricamente permitir condições de controle e segurança aos seus moradores, mas que de fato isolam e fragmentam amplos trechos dos novos tecidos urbanos. $O$ aumento da insegurança social, expresso pelas desigualdades existentes, associado a uma omissão e/ou incompetência do poder público legalmente constituído, de gerenciar o espaço urbano, induz, mas não justifica a tomada de tais medidas, que proliferam por todo o país. Pequenas vilas urbanas, grandes superquadras, condomínios horizontais inteiros estão murados e controlados por guaritas e as vias ao seu redor são totalmente esvaziadas de vida urbana, servindo de meras passagens e acessos, onde raramente se pode encontrar um pedestre.

Para o entorno desses lugares, a expressão vulgar e inadvertidamente utilizada "o espaço público morreu" poderia ser utilizada com correção. Para os demais pontos, o oposto pode se afirmar. Talvez em nenhum momento do século 20 o espaço público esteja sendo tão utilizado, a despeito das vicissitudes do cotidiano.

Tanto nos bairros pobres como ricos, o espaço público passa por um processo de reapropriação significativa, principalmente no período após a denominada "crise do petróleo", quando foram formalmente valorizados os hábito de andar a pé, da prática de esportes e o correr, no contexto urbano. Pelas cidades do país é comum o caminhar informal de pessoas das mais diferentes idades e a corrida, até por pontos muito insólitos como a beira de uma estrada ou de uma via urbana de trânsito rápido.

Praias, parques, algumas vias urbanas, praças, etc., estão sempre repletas de usuários e os fins de semana são momentos aproveitados por largas parcelas da população para um lazer informal ou formal, nos quais são utilizados os espaços urbanos como uma das suas muitas ou únicas opçōes de lazer. Na realidade, o lazer virtual, o ouvir rádio e a televisão se constituem na principal forma de lazer urbano do século, substituindo leituras, serões, saraus e os passeios nos jardins, nos hábitos da maioria da população. 
Por outro lado, as formas de lazer intra-urbano se diversificam ao extremo, tanto ao ar livre como o próprio uso da praia e os parques temáticos (os primeiros ainda em implantação no país), como aqueles contidos nas construções, como o cinema (na primeira metade do século - uma das formas de lazer mais populares), os shopping centers e centros esportivos e culturais, possibilitando a muitos uma maior gama de opções de recreação.

Figura 10 - As lagoas da Barra sofrem, no final do século 20, um processo de polvição constante

Fonte: Foto do autor (1999)

Figura 10 A - São Luís do Maranhão Revitalização cênica. Fonte: Francine Cramacho
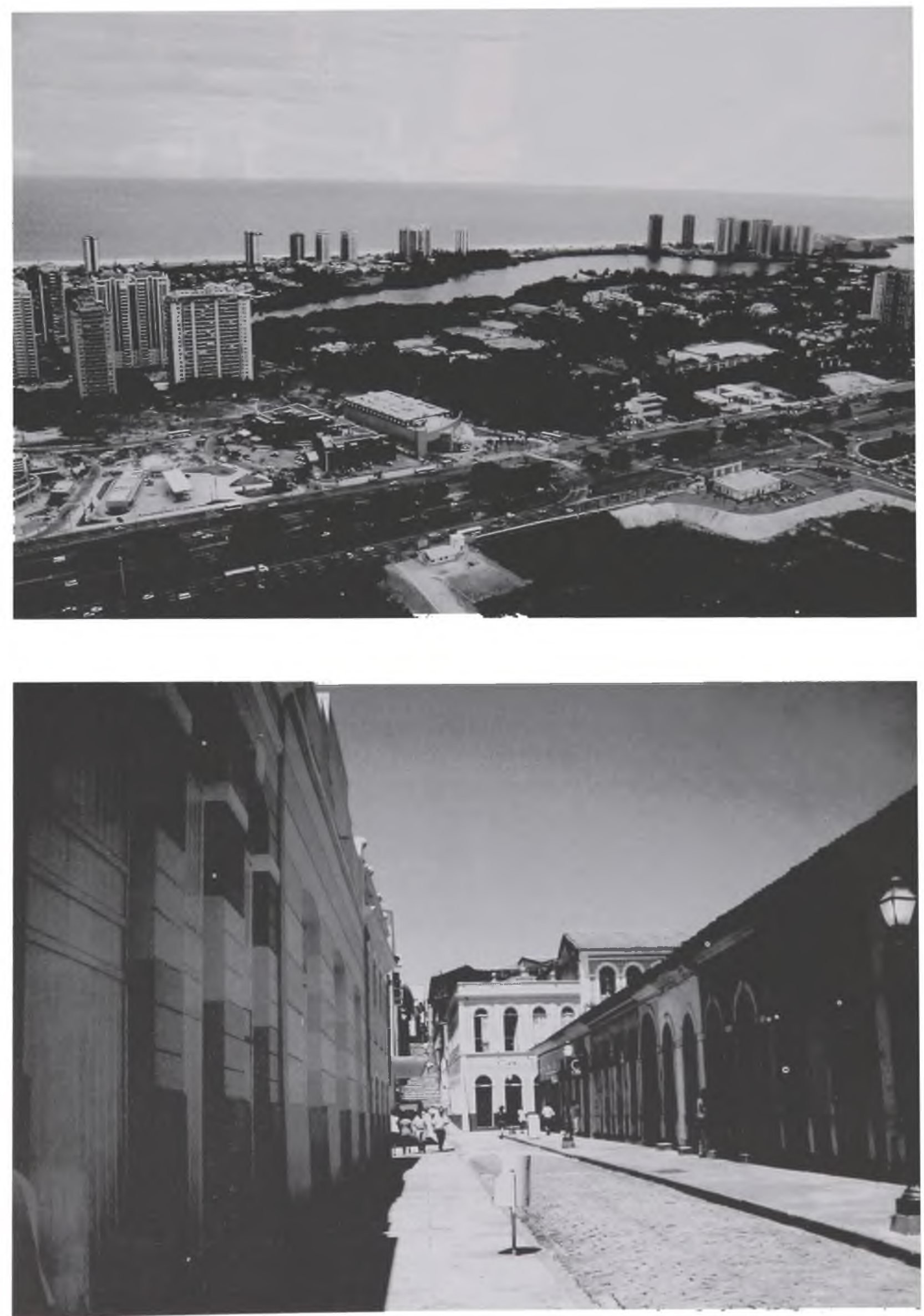


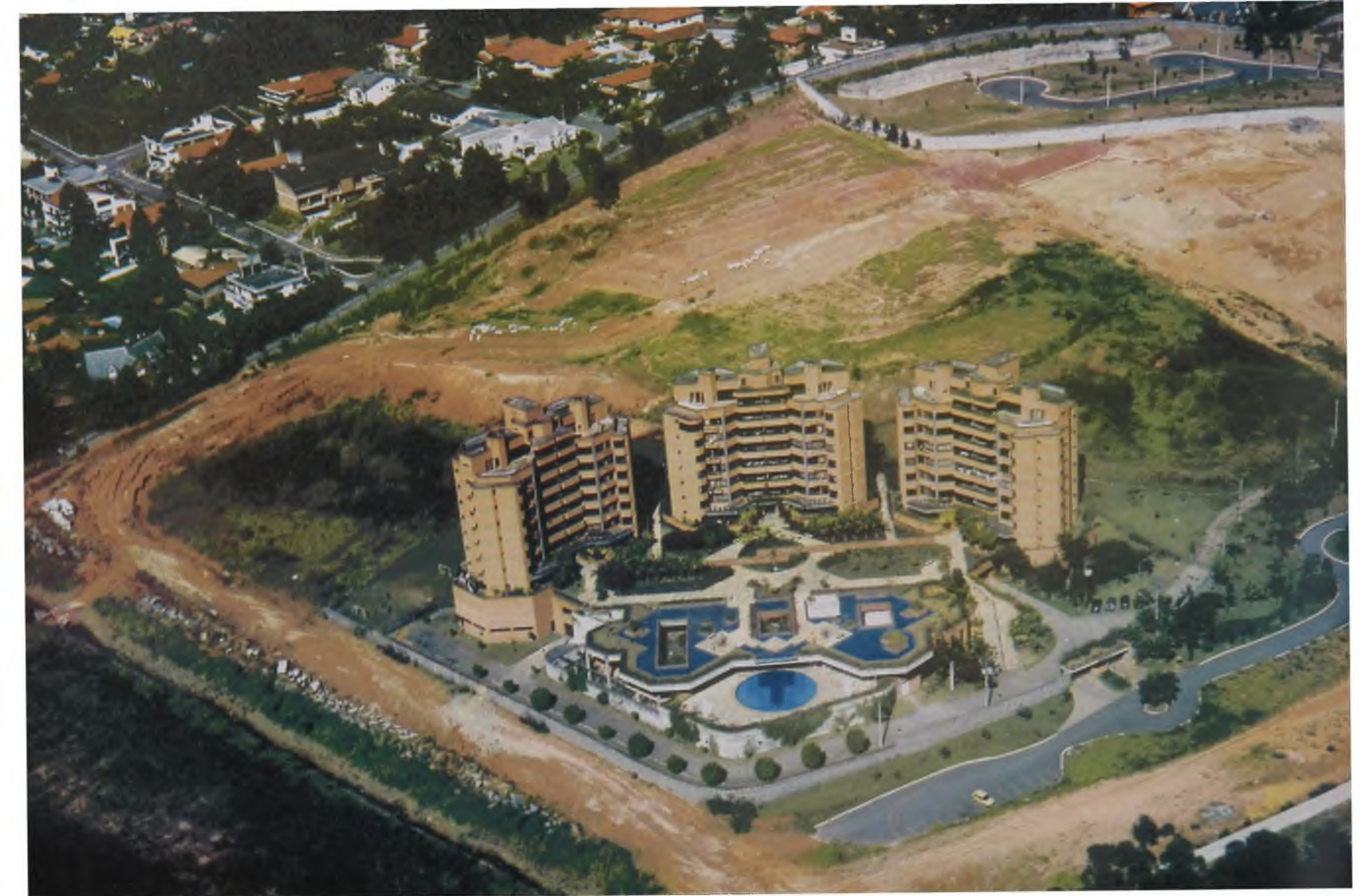

Figura 11 - Novas áreas - grandes terrenos, a reconstrução e o ajardinamento - Alphaville - Barveri - SP Fonte: Foto do autor (1998)

Não existe a morte do espaço público, mas a recodificação e a especialização de suas formas de apropriação, que são adequadas às formas de arranjos sociais que se configuram. Não se pode, por exemplo, dizer que uma rua de área central tomada por vendedores ambulantes, os populares camelôs, esteja morta, mas sim que não é mais destinada para o uso das elites, para o seu flanar ou para suas compras.

Muitas das novas figuras urbanas como o shopping center, a avenida ladeada por negócios de fast food ou delivery, os centros administrativos e financeiros distantes, por exemplo, são resultado direto do modelo de transporte priorizado no país, vinculado ao automóvel, ao caminhão e ao ônibus em detrimento do transporte ferroviário e do metrô (para as grandes cidades). Tais estruturas são organizadas em função do uso cotidiano do automóvel e servem e favorecem diretamente aos contingentes sociais que o possuem.

Outras estruturas, como os parques e praças públicos, são valorizadas em função de uma real demanda social por tais equipamentos, que passam a ser preferenciadas nas políticas públicas de atendimentos para as populaçōes de menor poder aquisitivo. A sua implementação, em especial em períodos eleitorais, torna-se um procedimento cada vez mais comum nos principais centros urbanos brasileiros. 
O lazer recreativo exige a criação de espaços específicos para jogos e competições, e os parques, principalmente as praças, mostram-se como locais adequados para tal fim, substituindo antigos terrenos baldios e várzeas, que antes eram livremente utilizados por todos para - lazer, e, pouco a pouco, dão lugar à urbanização em expansão. $O$ parque público, por outro lado, aumenta em número e passa, como seus congêneres europeus e americanos do século 19, a ser construído também para o lazer da grande massa, destinando-se a oferecer a este público, dentro do meio urbano, espaços arborizados e cenicamente tratados, que de certo modo o remeta aos bucólicos espaços do entorno das pequenas cidades, como campos, bosques e lagos, e que já não mais são acessíveis a todos aqueles que habitam as grandes aglomerações urbanas.

Figura 12 - Jardins na rua Aracaju Higienópolis em estilos pósmodernistas. (Sāo Paulo)

Fonte: Foto do autor (1999)

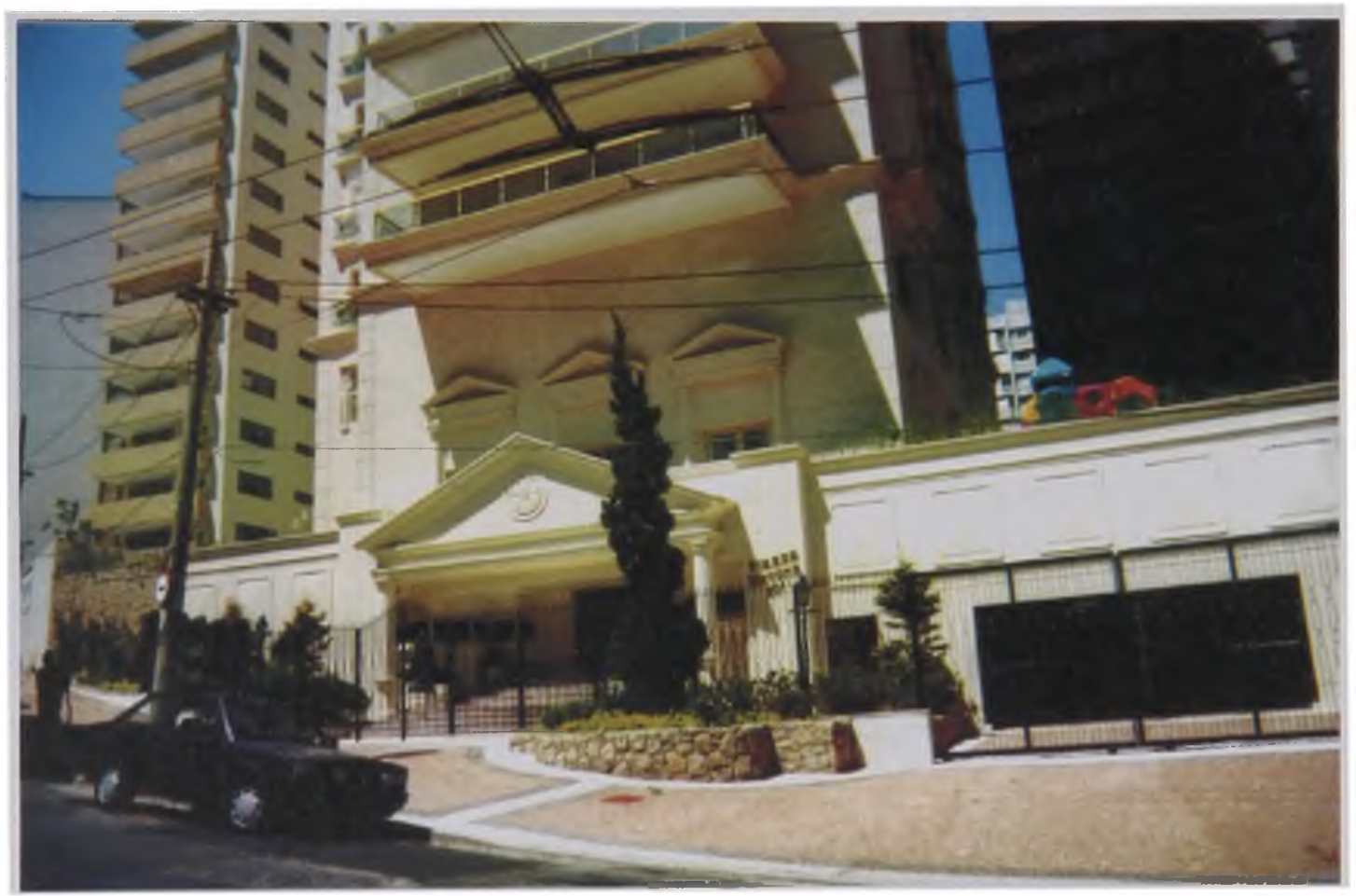

Figura 13 - Grandes jardins tradicionais junto a prédios modernos. Vista aérea do Morumbi

Fonte: Foto do autor (jun. 1998,

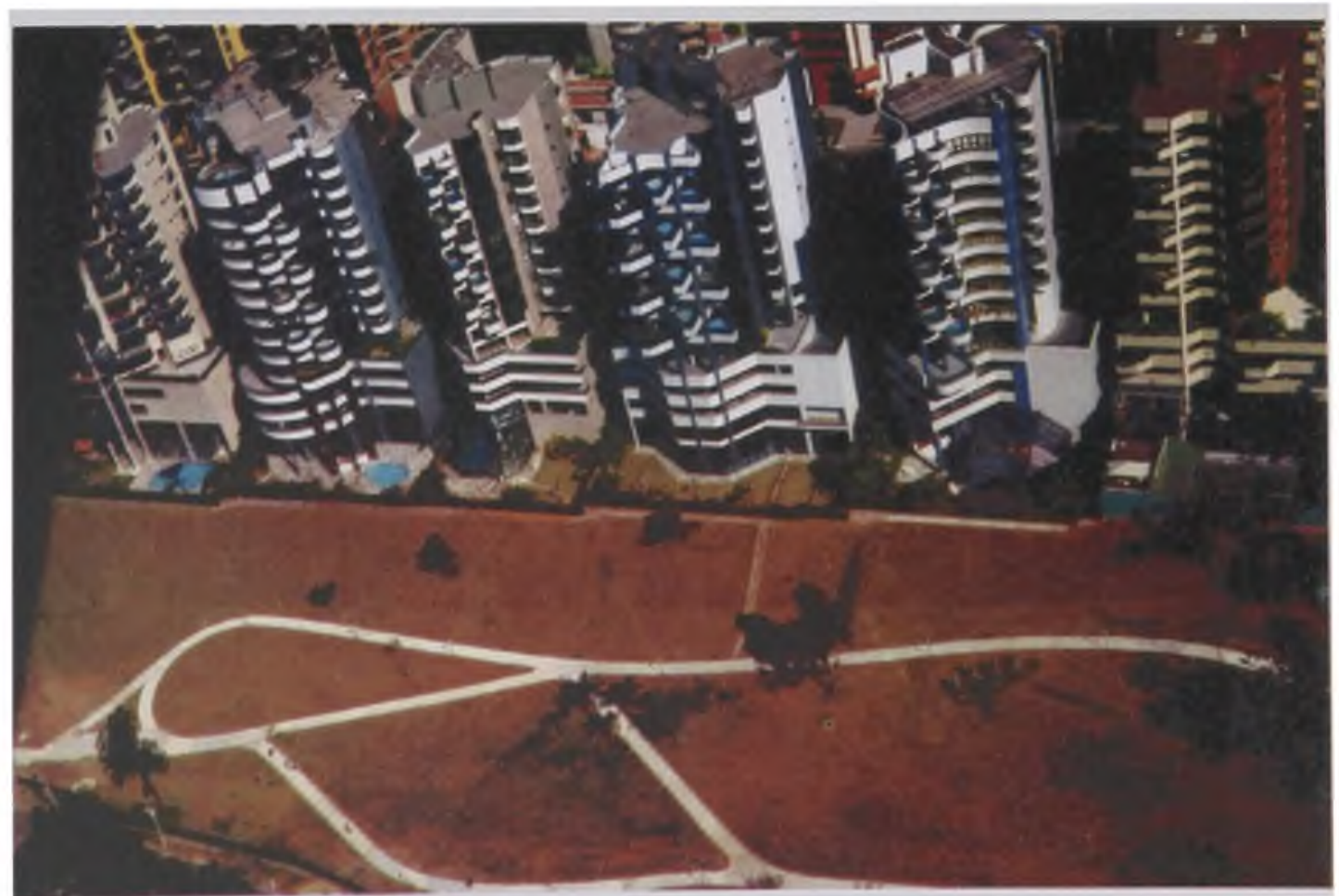


Os novos parques urbanos construídos se localizam, em geral, nos subúrbios e periferias urbanas e destinam-se ao lazer das camadas mais populares da sociedade e, por muitas vezes, também à preservação de remanescentes de alguns ecossistemas, como matas (caso de parques em Curitiba, Salvador e Belo Horizonte) ou de várzeas, com manguezais (caso do Parque do Cocó em Fortaleza).

O parque no Brasil, como se sabe, não foi introduzido, de fato, como uma necessidade urbana das massas, e sim como um espaço para as elites emergentes do império e da República Velha.

\section{Centros da Cidade - Do Esvaziamento à Cenarização}

A partir dos anos 50, observa-se uma mudança das formas de apropriação, uso e configuração de muitas das velhas áreas centrais das cidades brasileiras, com o nítido esvaziamento funcional de trechos importantes de tais áreas, com o deslocamento de atividades comerciais e serviços para outros pontos das cidades, tais como novos pólos de serviços, como as avenidas Paulista e Brigadeiro Faria Lima na cidade de São Paulo, ou como os centros administrativos de Salvador, Campo Grande, Cuiabá e Curitiba. Estes fatos, favorecidos por uma legislação permissiva, que permita a livre expansão de tais atividades por toda a cidade (caso de São Paulo), ou pela própria iniciativa do poder público de transferir suas instalações para fora das já congestionadas e saturadas áreas centrais, em vez de adaptá-las às novas formas de uso, permite uma mudança radical na forma de uso e ocupação de tais áreas, que, em muitos casos, deixam de ser "o centro" de todas as atividades principais das cidades para se especializarem em umas poucas; a simples saída de todas as secretarias de Estado de uma área central não só retira de tal espaço centenas de usuários, como leva consigo uma série de outros profissionais e instituições, que lhes prestam apoio ou thes oferecem serviços.

Por outro lado, o incremento do comércio popular, que muitas vezes ocorre, é visto como uma depauperação do local, já que este não é mais freqüentado pelas camadas médias e altas da população, sendo isto considerado por muitos como uma decadência.

São também freqüentes os procedimentos ditos de "revigoração" de tais áreas, alguns se caracterizando pelo restauro turísticocenográfico de velhas artérias e edifícios transformados em elegantes calçadões e lojas, ou apenas pelo simples tratamento das vias com pisos homogêneos, que são equipadas com bancos, quiosques, plantas e floreiras e que se destinam ao tráfego pleno de pedestres, visando um eventual e desejado incremento comercial. Tais medidas se mostraram em geral positivas, favorecendo a manutenção e a 


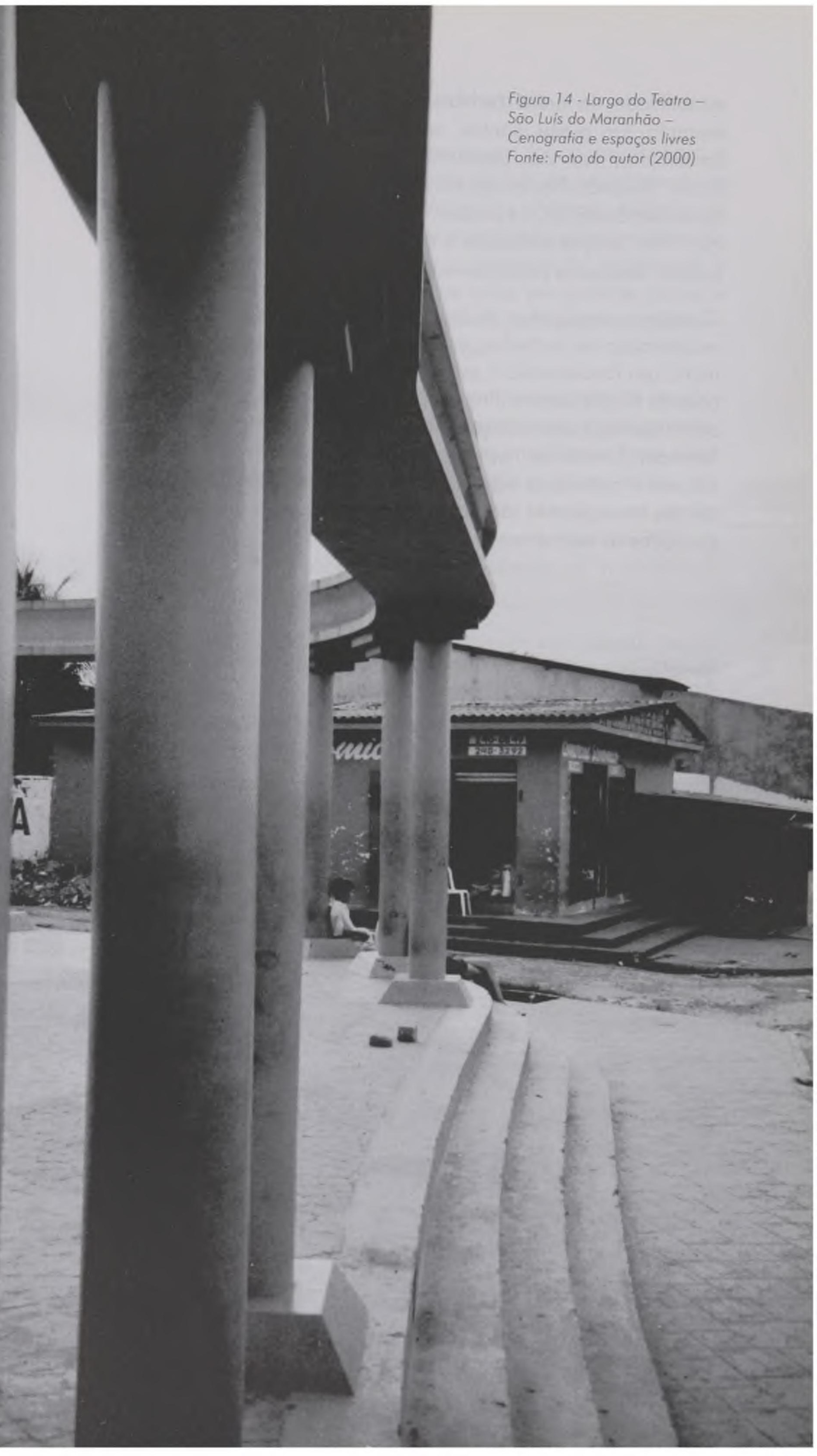


estabilidade de áreas centrais em Curitiba e Florianópolis, por exemplo. Em outros pontos, após um sucesso inicial (em termos comerciais), tais vias pedestrianizadas, os populares calçadões, foram "invadidas" ou ocupadas por vendedores ambulantes, tornando-se de trânsito difícil e passam a exigir cuidados extras de manutenção, nem sempre efetuados e afastando alguns dos segmentos de público desejados pelos comerciantes.

O restauro cenográfico de áreas centrais antigas com a pintura e a recuperação de fachadas, aos poucos, tornou-se uma prática comum, ora favorecendo a estabilidade funcional de alguns centros, caso do Rio de Janeiro (Projeto Corredor-Cultural) ou levando a um outro tipo de especialização, no caso para fins turísticos, como em Salvador. Elimina-se, neste caso de vez, possibilidades de uso diversificado e favorece-se algumas formas de segregação urbana, já que em tais áreas os usos são restritos e não interessa a sua apropriação por todos os segmentos sociais.

Figura 15 - Largo do Teatro - Sõo Luís do Maranhão. O pátio frontal delimitado pelas colunas gregas Fonte: Francine Gramacho

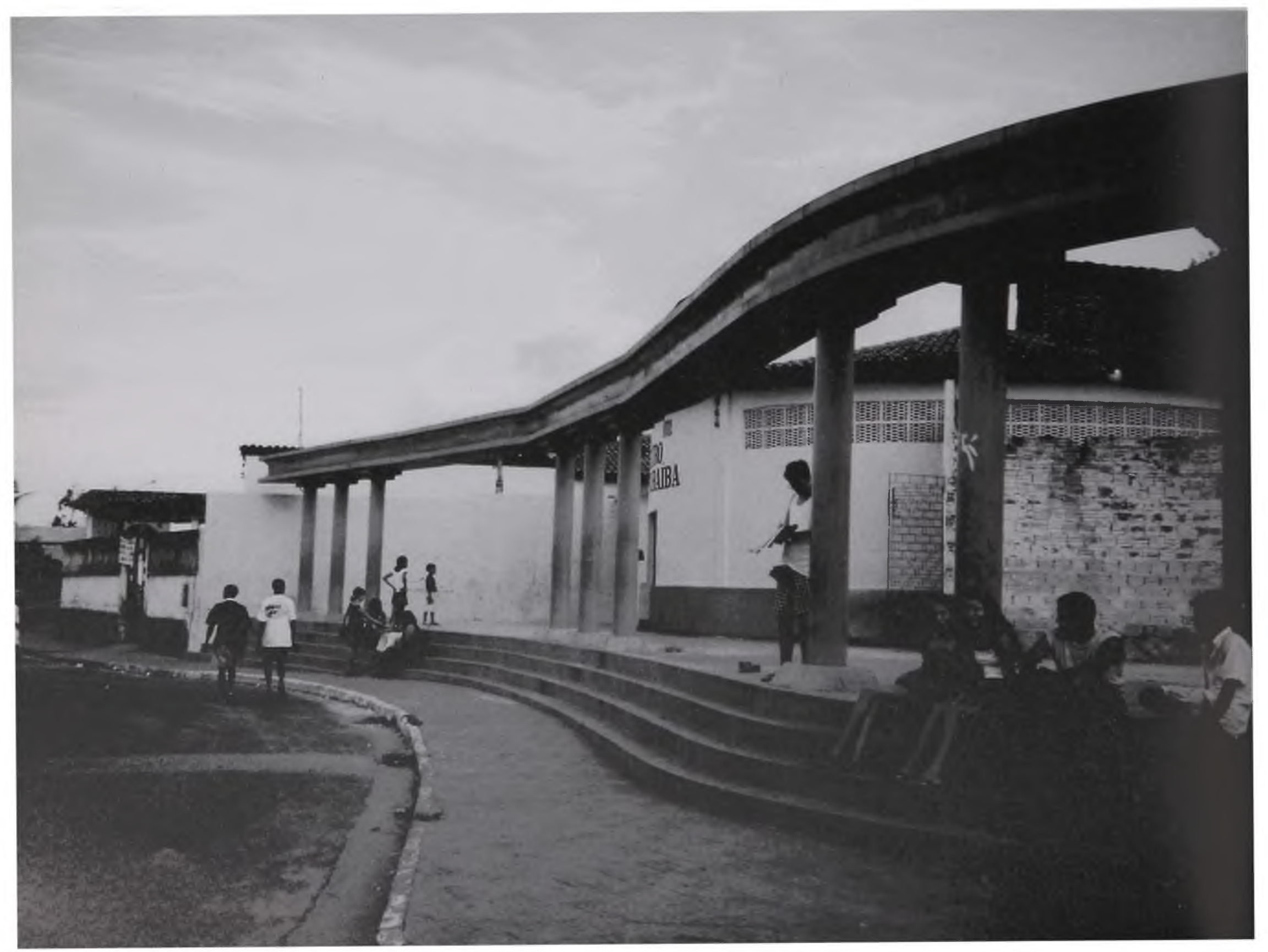




\section{Valorização de Questões Ambientais}

A Constituição de 1988, pela primeira vez, formaliza, no país, a intenção já latente em alguns setores sociais de se conservar os recursos naturais e paisagísticos nacionais. A mata atlântica, a Amazônia, o Pantanal e a zona costeira se transformam em áreas de interesse para a conservação e a preservação ambiental e paisagística, e o discurso ecológico se torna um mote de planos e projetos dos mais diversos, sendo absorvido, ainda que parcialmente, pelos mais diversos segmentos sociais.

Os termos ecológico e ambiental se tornam corriqueiros no vocabulário cotidiano e servem como etiquetas para secretarias de governo, parques públicos e até a empreendimentos imobiliários "bem dotados de áreas ajardinadas ou bosques" aos quais se atribui, por muitas vezes, o valor ambiental como uma estratégia de venda. Nestes, somente algumas vezes se observa a real intenção de conservar este ou aquele recurso, ainda assim de um modo genericamente cenográfico.

Paralelamente, as perdas ambientais se tornam uma questão básica nacional, já que importantes segmentos da mata atlântica ainda remanescentes no início do século 20 desaparecem, bem como grandes extensões de cerrado e floresta amazônica. Paralelamente, nos centros urbanos a polvição e a destruição de rios e lagos são uma constante; a erosão e a queda de encostas fazem parte do cotidiano, e o assoreamento de canais, rios e barras portuárias são fatos comuns, notados especialmente na época das grandes chuvas. Lixo em excesso, não - tratado e disposto nos corpos d'água e, principalmente, uma absoluta falta de prioridade pública nos investimentos de tratamento e esgotamento sanitário fazem da polvição, tanto do solo quanto, sobretudo, dos corpos d'água, o principal problema ambiental urbano do país.

Belas praias, cercadas por edifícios altos e alvos, com mar de um azul impecável, estão poluídas e sua utilização não é aconselhável justamente nas épocas de "pico", no veraneio, quando o lixo do esgoto em quantidade dos grandes contingentes de turistas é levado de um modo direto ou indireto até as praias, a muitos rios e canais urbanos que estão total ou parcialmente destruídos, no tocante à sua flora e fauna e não são mais adequados ao banho, ou a outra forma de lazer, como pesca ou canoagem, por exemplo.

No caso, a paisagem ainda parece, em geral, bela ao grande público, com o rio mostrando sua imagem tranqüila à visão, impressão esta totalmente alterada com a percepção de odores fortes 
exalados pelo corpo d'água ou com a descoberta de restos de lixo ou sucatas nas suas margens.

São estes, polvição da água associada à erosão do solo, especialmente de encostas em épocas de grandes chuvas e a perda da cobertura vegetal nativa, não só dentro das áreas urbanas, como pelos campos afora, os principais problemas ainda não resolvidos dentro da paisagem urbana brasileira, que se arrastam durante todo o século, perpetuando-se no cotidiano da cidade.

A tradição de planejamento urbano-sanitarista de Saturnino de Brito, apesar de importante, especialmente em centros como Santos e Vitória, não serve e não serviu de parâmetro efetivo para a organização dos novos e velhos aglomerados urbanos. A própria Barra da Tijuca, na cidade do Rio de Janeiro, um dos projetos urbanopaisagistas do século, apesar de garantir a preservação de lagoas e outros corpos d'água, protegidas por parques públicos e áreas de conservação, tem a maioria de suas águas sujeitas a esgotamentos sanitários sem tratamento. De fato, são problemas especificamente ambientais que, no entanto, prejudicam e desvalorizam espaços urbanos dos mais diferentes tipos, inclusive áreas mundialmente conhecidas pelo seu valor paisagístico intrínseco, como a Baía de Guanabara ou as praias do litoral norte de São Paulo.

A primeira está bastante comprometida pelo constante processo de polvição das águas, derivada da metrópole carioca, e estas últimas apresentam, em épocas de temporada, problemas graves de qualidade das águas, nunca resolvidos de fato pelo Estado, sendo objeto de ações isoladas de investidores privados.

Outros problemas ambientais são comuns nas grandes cidades, como a polvição do ar, pouco percebida pelo conjunto da população, e a sonora, que por vezes limita e desvaloriza o uso e a ocupação do solo em áreas lindeiras às grandes vias.

\section{Rebatimentos no Projeto Paisagístico}

Se os princípios paisagísticos permeiam os mais diversos estudos, planos e intervenções urbanas, o projeto paisagístico, apesar de longa tradição que possui no país (mais de 200 anos de bons autores e intervençōes pontuais de qualidade), não é presença no cotidiano da sociedade brasileira como um todo.

164 De um lado, o projeto paisagístico se caracterizou, na grande maioria desse período, como uma forma de qualificação dos espaços das elites, a princípio concentrando-se nas áreas centrais junto 
Figura 16 - Campo de Santana - O grande parque urbano carioca do séc. XIX - Obra de Glaziou Fonte: Foto do autor (1999)

Figura 17 - Parque das Mangabeiras praça principal projeto de Burle Marx Fonte: Foto de Luis Mauricio Brandão (1996)

aos edifícios do poder e do grande capital financeiro e pelas ruas, elegantes bulevares e palacetes das elites nacionais.

Uma vista geral sobre o conjunto dos projetos paisagísticos nacionais apresenta um quadro que confirma tal afirmação. As obras de Auguste Glaziou, no século 19 e Roberto Burle Marx, no século 20, os dois mais expressivos arquitetos paisagistas dos dois séculos, mostram-se, a princípio, sempre a serviço das elites nacionais. Observa-se hoje que muitas de suas obras são, ao final do século, comumente utilizadas pelo todo da população, mas mesmo obras populares, como o Campo de Santana, no centro do Rio de Janeiro (de Glaziou) ou o Parque das Mangabeiras (de Burle Marx, em Belo Horizonte) situam-se ou situavam-se em áreas ocupadas pelas elites.
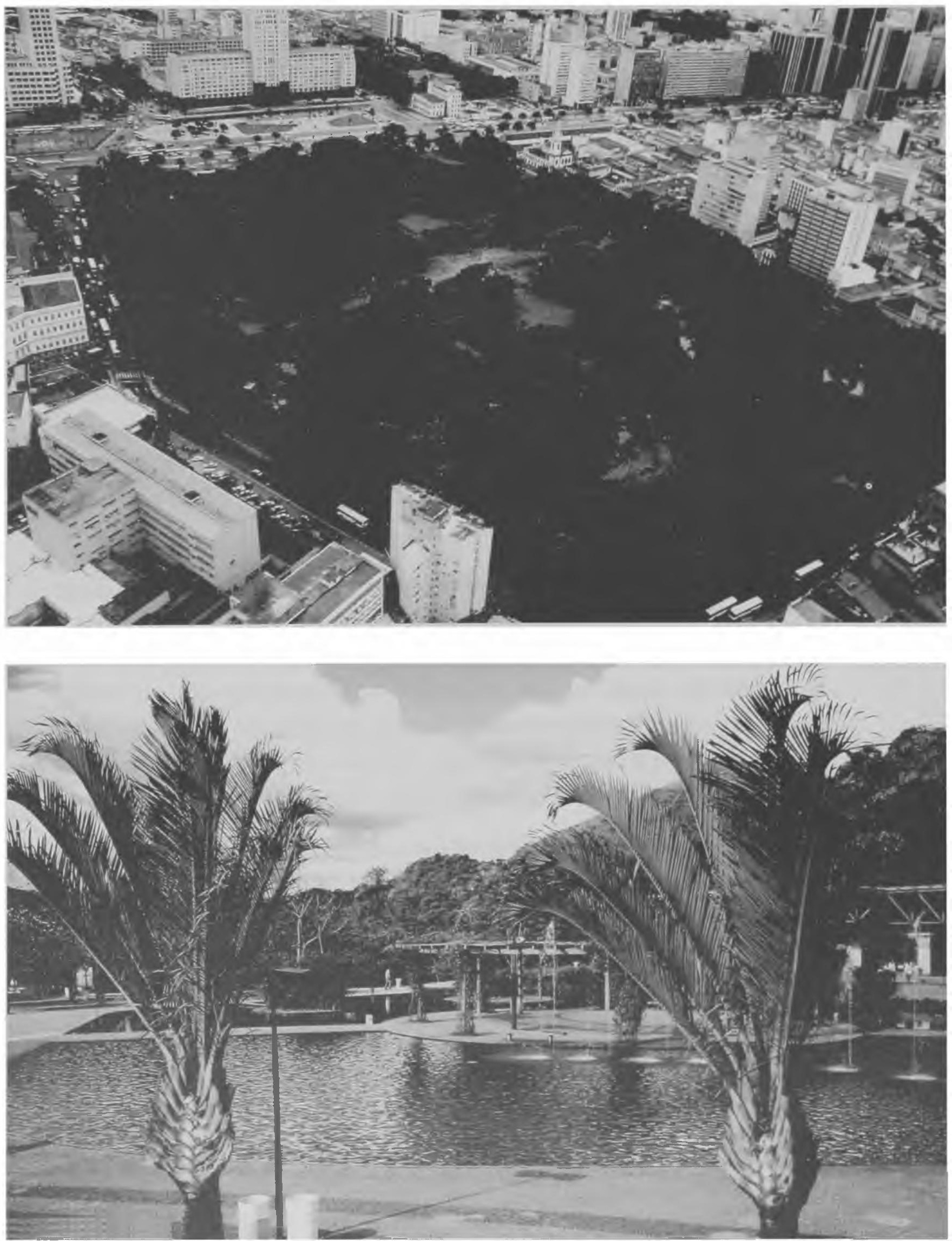
Por outro lado, somente a partir da segunda metade do século 20 se amplia a demanda por projetos paisagísticos em áreas urbanas mais amplas, tanto na esfera pública como privada. No âmbito estatal, por exemplo, a crescente demanda por novas praças, parques, calçadões, etc., faz com que um número significativo de profissionais se dedique à criação de projetos para tais áreas. No campo privado o crescimento do processo de verticalização pelo país afora, derivada de um mercado imobiliário em expansão e que visa atender, além das elites, às camadas médias e alguns setores de menor renda, tem no tratamento dos espaços livres do lote verticalizado um dos fatores de venda de seus produtos.

São comuns, então, os projetos de pátios e jardins para pequenos e grandes condomínios verticais e o mercado para projeto paisagístico nacional se desenvolve de um modo expressivo nos centros urbanos principais.

Formalmente as mudanças são grandes, o nacionalismo exacerbado dos anos 40,50 e 60 foi banido e substituído por um liberalismo formal, que admite o uso de formalismos, estético-formais derivados de um pós-modernismo arquitetônico adaptado de manuais estrangeiros, até uma visão ambientalista, que valoriza, como nos tempos do modernismo, a flora nacional, pregando ainda a conservação de restos, significativos ou não, de matas nativas.

Este é um período de liberdade projetual, que sucede, a partir dos anos 90 , a quase 50 anos de um projeto moderno funcionalista, na qual se criou uma identidade própria formal-funcionalista para o paisagismo nacional, que induziu todos os projetistas a seguir padrōes estritos de projeto.

De fato se perde o caráter nacionalista, até então vigente, em função da citada liberdade, expressa pelo uso indiscriminado de pórticos e colunatas, por um neo-ecletismo escandaloso, pelo jardinismo romântico, que por vezes remete ao jardim tradicional francês ou inglês. Paralelamente, observa-se o crescimento da pesquisa formal feita por profissionais diversos, que sozinhos, isolados em suas cidades, criam formas alternativas para a configuração de seus projetos.

Funcionalmente as mudanças são poucas, observando-se a manutenção de velhos programas, tanto nos espaços públicos como privados, apenas revestidos de novas roupagens.

Como fato de destaque, a especialização radical de usos das praças públicas, algumas prescritas como verdadeiras praças de alimentação e uma grande maioria delas agora produzidas como espaços para recreação, especialmente para práticas esportivas. 


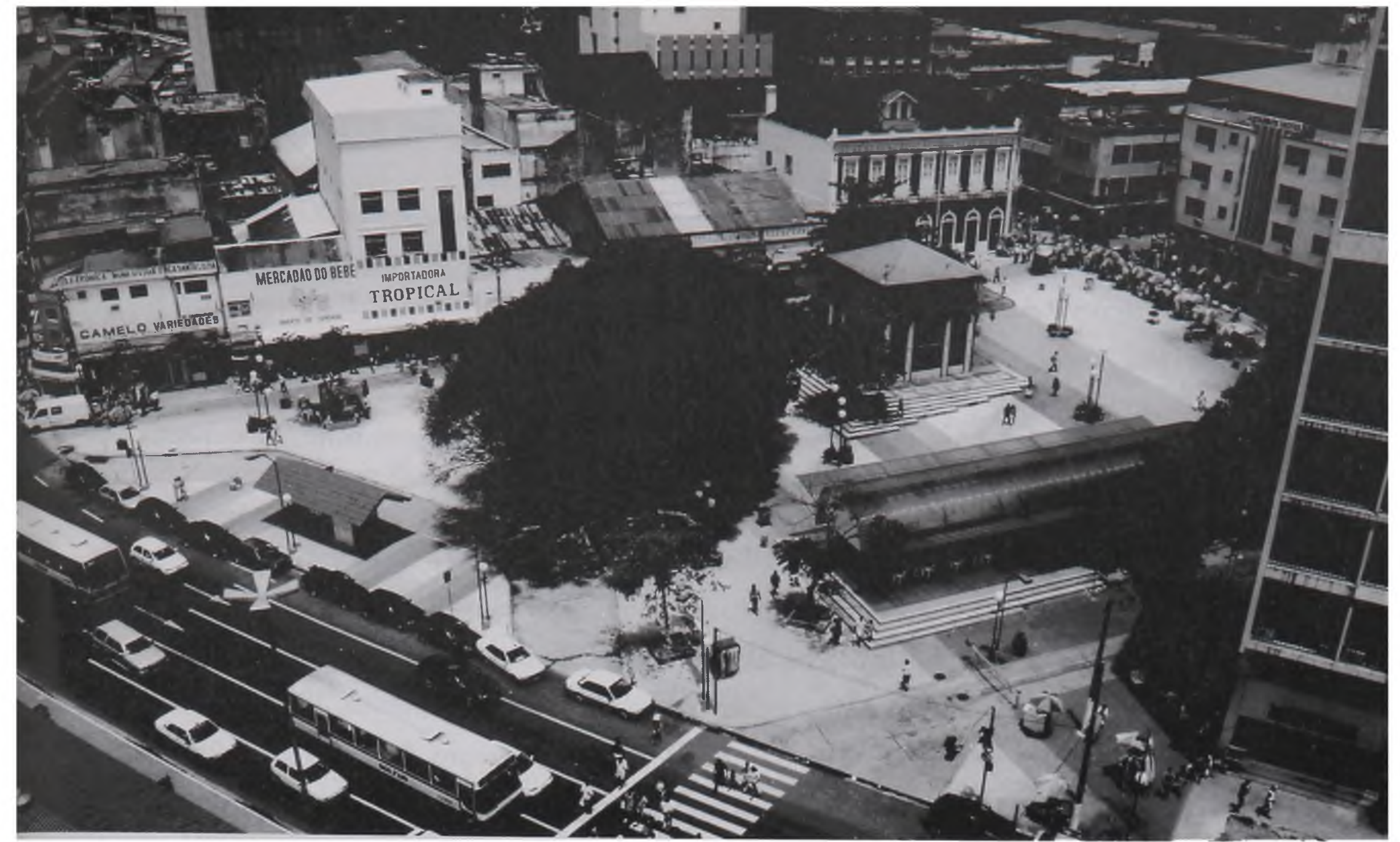

Figura 18 - Nova forma para a praça Ferreira Aranha - Manaus - Também um espaço para alimentação Fonte: Foto de Cesar E. Assis (1998)

\section{Bibliografia}

ABBUD, Benedito. A obra do arquiteto paisagista Roberto Coelho Cardozo. São Paulo: TGI, FAUUSP, 1974.

BARDI, Pietro Maria. The tropical gardens of Burle Marx. Amsterdã, RJ: Colibris, 1964.

BARTALINI, Vladimir. Praças do metrô: Enredo, produção, cenário, atores. São Paulo, 1988. Dissertação (Mestrado), - Faculdade de Arquitetura e Urbanismo, Universidade de São Paulo.

BRUNO, Hernani da Silva. História e tradiçōes da cidade de São Paulo. São Paulo: Huditec, v. III, 1984.

CADERNOS BRASILEIROS DE ARQUITETURA. Paisagismo. São Paulo: Projeto Editores Associados, v. 5, 1980.

. Paisagismo II. São Paulo: Projeto Editores Associados, v. 11, 1982.

CARDOZO, Omar de A. Arquitetura paisagística do ecletismo ao moderno: Roberto Cardozo. Relatório Final de Pesquisa CNPq. São Paulo: FAUUSP, 1990.

CENTRO CULTURAL BANCO DO BRASIL. A paisagem desenhada: O rio de Pereira Passos. Rio de Janeiro, 1994.

CULLEN, Gordon. Paisagem urbana. Rio de Janeiro: Ediçōes 70, 1971.

DEGREAS, Helena Napoleon. Paisagem paulistana - Sincretismo e fragmentação. São Paulo, 1999. Tese (Doutorado) - Faculdade de Arquitetura e Urbanismo, Universidade de Sāo Paulo.

DESTÁCIO, Mauro Celso. Áreas verdes em São Paulo: Retratos, cenários e paisagens. Trabalho de conclusão de curso de jornalismo. São Paulo: ECAUSP, 1998. 
DOURADO, Guilherme Mazza (Org.). Visões de paisagem: Um panorama do paisagismo contemporâneo no Brasil. São Paulo: ABAP, 1997.

FAVOLE, Paolo. La plaza en la arquitectura contemporánea. Barcelona: Gustavo Gili, 1995.

FRANCO, Maria de Assunção Ribeiro. Desenho ambiental: Uma introdução à arquitetura da paisagem com o paradigma ecológico. São Paulo: Annablume, 1997.

FROTA, Lélia Coelho. Burle Marx: Paisagismo no Brasil. São Paulo: Câmara Brasileira do Livro, 1994.

GONÇALVES, Lisbeth Rebollo (Org.). Arte e paisagem: A estética de Roberto Burle Marx. São Paulo: Museu de Arte Contemporânea da USP, 1997.

GUARALDO, Eliane. Arquitetura paisagística e a cidade, do ecletismo ao moderno. Relatório Final de Aperfeiçoamento. São Paulo: CNPq, FAUUSP, 1990.

KLIAS, Rosa Grena. Parques urbanos de São Paulo. São Paulo: Pini, 1993.

LAURIE, Michael. Introduction a la arquitectura del paisaje. Barcelona: Gustavo Gili, 1983.

LEENHARDT, Jacques (Org.). Nos jardins de Burle Marx. São Paulo: Perspectiva, 1994.

LENCLOS, Jean Philippe. Les coulers da la France. Maisons et paysages. Paris: Sevpen, 1957.

LYALL, Sutherland. Landscape - Diseño del espacio público. Parques. Plazas. Jardines. Barcelona: Gustavo Gili, 1991.

MACEDO, Silvio Soares (Org.). Paisagem e ambiente - Ensaios. São Paulo, FAUUSP, v. 1, n. 10, 1997.

São Paulo, paisagem e habitação verticalizada: Os espaços livres como elementos de desenho urbano. São Paulo, 1987. Tese (Doutorado) - Faculdade de Arquitetura e Urbanismo, Universidade de São Paulo.

. Higienópolis e arredores: Processo de mutação de paisagem urbana. São Paulo: Edusp/ Pini, 1987.

MACEDO, Silvio Soares et al. Quadro do paisagismo no Brasil. Relatório final de pesquisa. São Paulo: FAUUSP., 1997.

MACIEL, Marieta Cardoso. O projeto em arquitetura paisagística - Praças e parques públicos de Belo Horizonte. São Paulo, 1998. Tese (Doutorado) - Faculdade de Arquitetura e Urbanismo, Universidade de São Paulo.

MACHADO, Denise B. Pinheiro (Org.). História da cidade e do urbanismo. In: IV SEMINÁRIO, v. 1 e 2, PROURB. 1996. Rio de Janeiro. Anais. Rio de Janeiro, 1996.

MARX, Murilo. A cidade brasileira. São Paulo: Melhoramentos/ Edusp, 1980.

MESQUITA, Alfredo. A vida elegante em Sāo Paulo na década de trinta. Vogue Brasil. Sāo Paulo: Carta Editoral Ltda, jul. 1998.

MIGLIORINI, Franco. Verde urbano - Parchi, giardini, paesagio urbano: Lo spazio aperto nella costruzione della città moderna. Milāo: Franco Angeli, 1992.

MONTERO, Marta Iris. Burle Marx - Paisajes líricos. Buenos Aires: Iris Editor, 1997.

MORAIS, Fernando, SEVCENCO, Nicolau. História da vida privada no Brasil. São Paulo: Schwarcz, v. 3, 1998.

MOTTA, Flávio Lichtenfels. Roberto Burle Marx e a nova visão da paisagem. São Paulo: Nobel, 1983. 
MOUGHTIN, J. Cliff. Urban design: Street and square. Oxford, Butterworth: Heinemann LTD., 1992.

NEEDVELL, J. Belle époque tropical. São Paulo: Companhia das Letras, 1993.

NEVES, Ézia. Praças de Belém. São Paulo, 1997. Dissertação (Mestrado) - Faculadade de Arquitetura e Urbanismo, Universidade de São Paulo.

OBA, Leonardo Tossiaki. Curitiba e seus marcos referenciais urbanos. São Paulo, 1998. Tese (Doutorado) - Faculdade de Arquitetura e Urbanismo, Universidade de São Paulo.

OLIVEIRA, Carmem L. Flores raras e banalíssimas: A história de Lota de Macedo Soares e Elizabeth Bishop. Rio de Janeiro: Rocco, 1995.

RECIFE (Cidade). Memória dos verdes urbanos do Recife/Usos e funções dos parques do Recife. Cadernos do Meio Ambiente. Recife: Secretaria de Planejamento. Urbanismo e Meio Ambiente, 1998, vol.1.

REIS FILHO, Nestor Goulart. Quadro da arquitetura no Brasil. São Paulo: Perspectiva, 1970.

RIO, Vicente del (Org.). Arquitetura: Pesquisa e projeto. Rio de Janeiro: Pró-editores; FAU-UFRJ, 1998.

SAKATA, Francine G. As linhas projetuais da arquitetura paisagística no desenho dos espaços livres dos edifícios de apartamentos. Relatório de iniciação científica. São Paulo: FAUUSP, 1994.

SECULT. Belém da saudade: Memória da Belém do início do século em cartões postais. Belém: Governo do Estado, Sec. da Cultura, 1996.

SEGAWA, Hugo. Ao amor ao público. São Paulo: Companhia das Letras, 1997.

SPIRN, Anne Whiston. O jardim de granito: A natureza no desenho da cidade. São Paulo: Edusp, 1995.

TÂNGARI, Vera Regina. Da avenida central ao Rio Cidade. O Rio de Janeiro se constrói a sua imagem. Texto de aula. Rio de Janeiro, 1997.

TERRA, Carlos Gonçalves. O jardim no Brasil do século XIX Glaziou revisitado. Rio de Janeiro: UFRJ, 1996.

TOLEDO, Cibele Boni de, CERATI, Tania Maria. Jardim Botânico de São Paulo. São Paulo: Instituto de Botânica, 1998.

TREIB, Marc. Garret Eckbo: Modern landscapes for living. Los Angeles, Londres: University of California Press, Berkeley, 1997.

ZOPPI, Mariella et al. Projettare con il verde. Firenze: Alinea, v. 1-5, 1994.

WHITE, William H. The social life of small urban spaces. Washington, D.C.: The Conservation Foundation, 1980. 